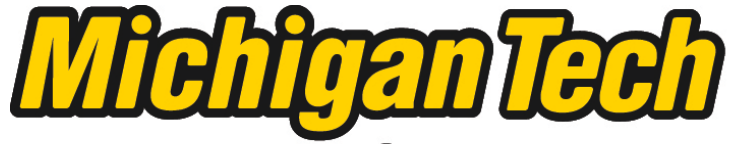 \\ Michigan Technological University Create the Future Digital Commons @ Michigan Tech
}

Dissertations, Master's Theses and Master's Reports - Open

Dissertations, Master's Theses and Master's

Reports

2014

\section{The Domestic Natural Gas Shortage in China}

Ting Guo

Michigan Technological University

Follow this and additional works at: https://digitalcommons.mtu.edu/etds

Part of the Agricultural and Resource Economics Commons, Economics Commons, and the Oil, Gas, and Energy Commons

Copyright 2014 Ting Guo

\section{Recommended Citation}

Guo, Ting, "The Domestic Natural Gas Shortage in China", Master's Thesis, Michigan Technological University, 2014.

https://doi.org/10.37099/mtu.dc.etds/778

Follow this and additional works at: https://digitalcommons.mtu.edu/etds

Part of the Agricultural and Resource Economics Commons, Economics Commons, and the Oil, Gas, and Energy Commons 


\title{
THE DOMESTIC NATURAL GAS SHORTAGE IN CHINA
}

\author{
By \\ Ting Guo
}

\begin{abstract}
A THESIS
Submitted in partial fulfillment of the requirements for the degree of MASTER OF SCIENCE

In Applied Natural Resource Economics
\end{abstract}

MICHIGAN TECHNOLOGICAL UNIVERSITY

2014

(C) 2014 Ting Guo 
This thesis has been approved in partial fulfillment of the requirements for the Degree of MASTER OF SCIENCE in Applied Natural Resource Economics

School of Business and Economics

Thesis Advisor:

Committee Member:

Committee Member:

School Dean:
Gary A. Campbell

Mark C. Roberts

Hugh S. Gorman

Gene Klippel 


\section{Contents}

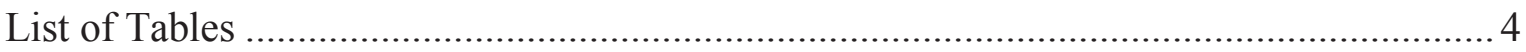

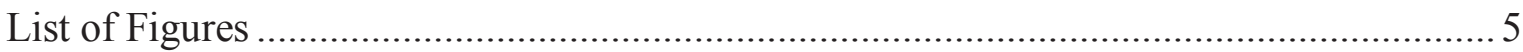

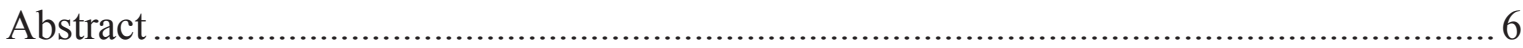

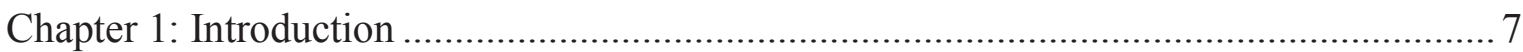

Chapter 2: Literature Review ………………………......................................... 9

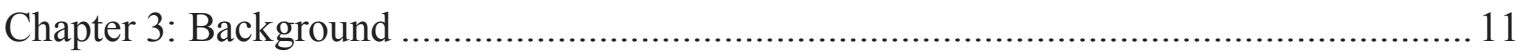

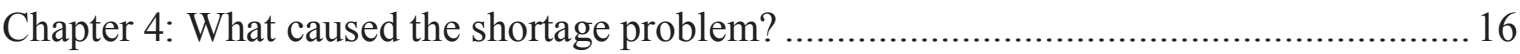

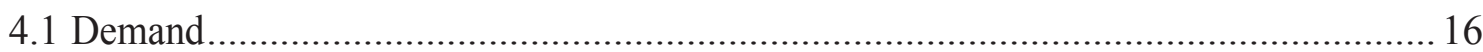

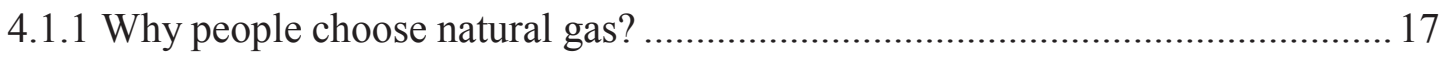

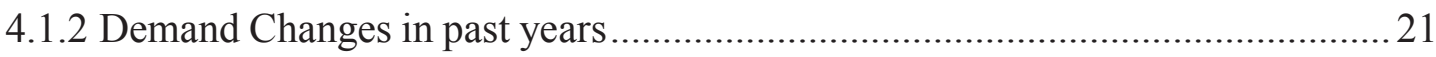

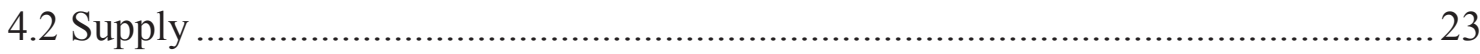

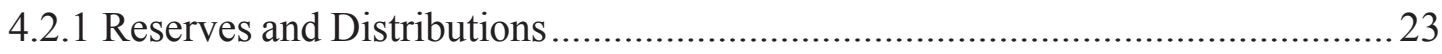

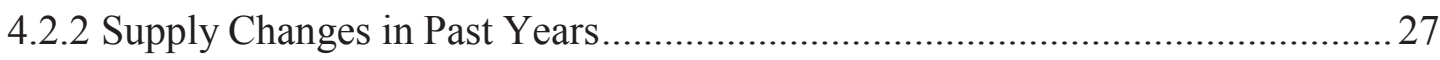

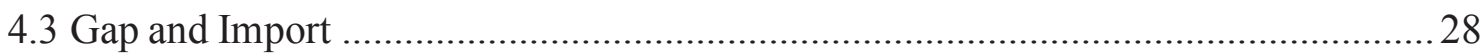

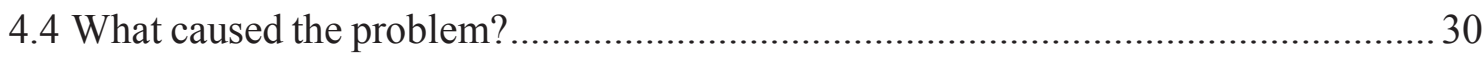

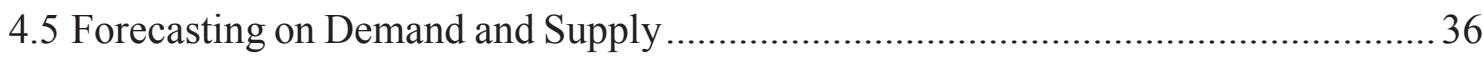

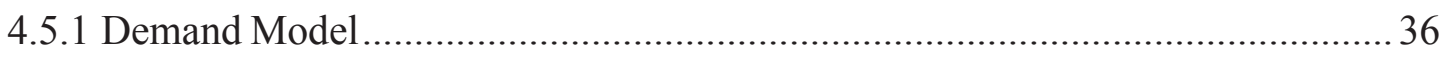

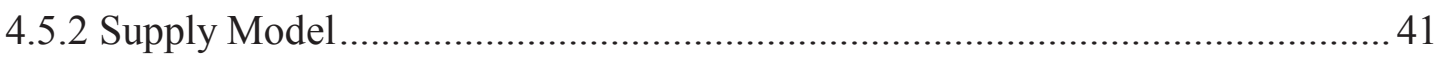

Chapter 5: Solutions and Suggestions .......................................................................... 44

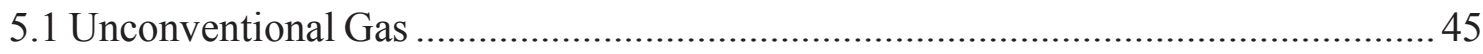

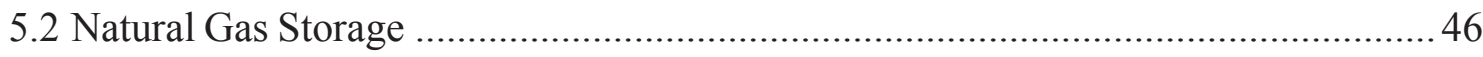

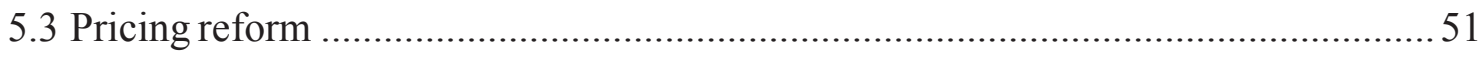

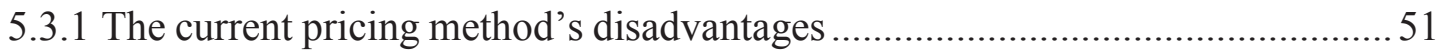

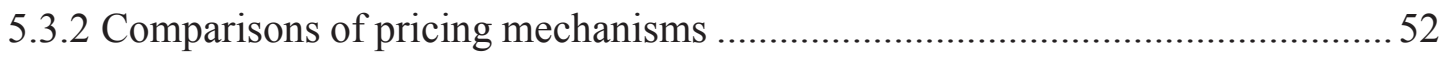

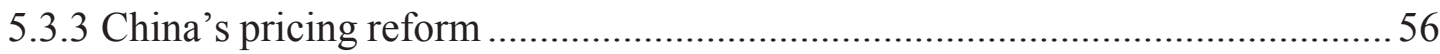

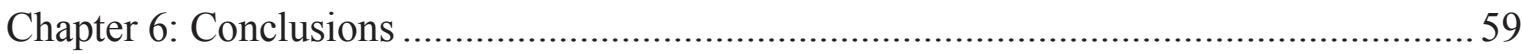

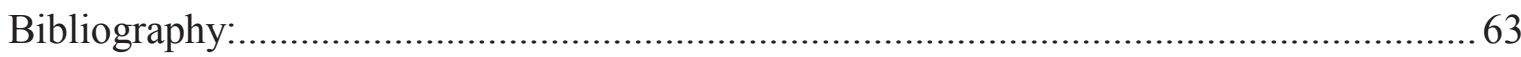




\section{List of Tables}

Table 1. Proportions of four main energy used in China................................13

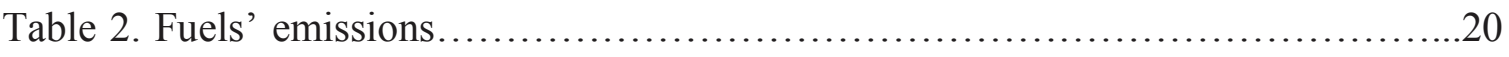

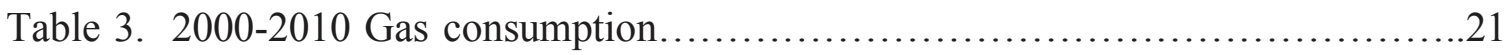

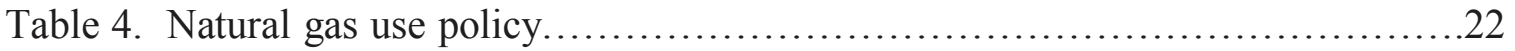

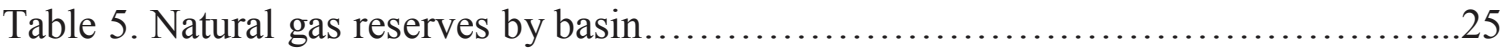

Table 6. Main information about pipelines..............................................

Table 7. Productions in three state-owned companies and total China..................28

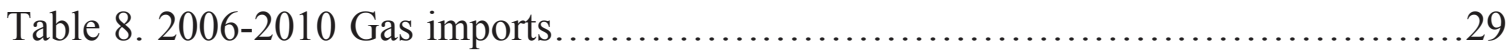

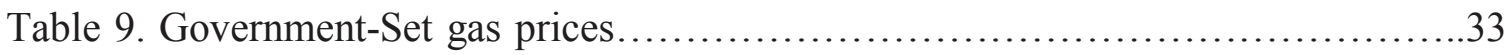

Table 10. Main pricing mechanisms in the world...................................52

Table 11. Natural gas prices in some Chinese cities..................................58 


\section{List of Figures}

Figure 1. Total energy use $\&$ its growth rate in China.................................11

Figure 2. Energy use in five economic entities....................................12

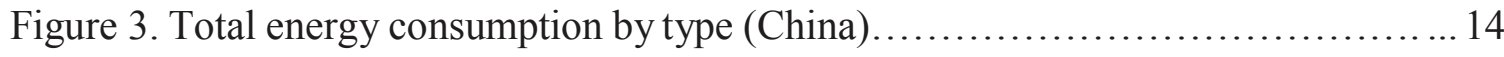

Figure 4. Total energy consumption by type (World) ................................. 14

Figure 5. Four kinds of energies' prices......................................... 18

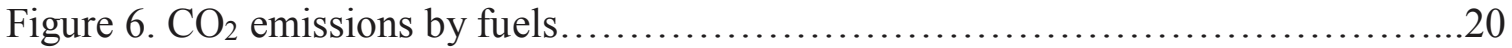

Figure 7. Distribution of natural gas in China......................................24

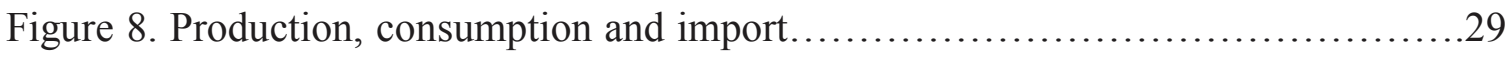

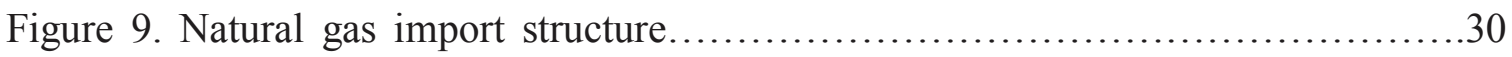

Figure 10. Demand-Supply Graph.................................................

Figure 11. Present pricing mechanism in China...................................... 34

Figure 12. System dynamics model for China's natural gas consumption.................37

Figure 13. Working gas in underground storage compared with the 5-year maximum and

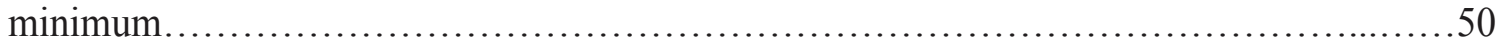

Figure 14. Used proportions of pricing mechanisms..................................54 


\section{Abstract}

This thesis analyzes the domestic shortage in the Chinese natural gas market. Both the domestic supply and demand of natural gas are growing fast in China. However, the supply cannot catch up with the demand. Under the present pricing mechanism, the Chinese natural gas market cannot get the equilibrium by itself. Expensive imports are inadequate to fill the increasing gap between the domestic demand and supply. Therefore, the shortage problem occurs. Since the energy gap can result in the arrested development of economics, the shortage problem need to be solved. This thesis gives three suggestions to solve the problem: the use of Unconventional Gas, Natural Gas Storage and Pricing Reform. 


\section{Chapter 1: Introduction}

People in primitive society drilled wood to make fire and so got the energy they needed in their daily lives. With the development of science and technology, humans started to use animal power, wind power and water power. In the $18^{\text {th }}$ century, people had new breakthrough in using energy efficiently; mineral fuels such as coal were discovered. After the invention of the steam engine, people entered the Mechanization era and coal was used as the main energy source in the $19^{\text {th }}$ century. Then the petrochemical industry that is based on oil and natural gas had extraordinary development. Now more and more people are starting to use natural gas. This kind of energy makes up a larger part of the overall energy mix than before.

To reduce greenhouse gases and avoid ecological disaster, developing a low carbon economy has become a global concern. The natural gas industry, as a cleaner energy, is entering a rapid development period. China has experienced the same process of energy use just as the other parts in the world. Following this tendency, the Chinese natural gas industry is in the fast lane. However, compared with these industries in developed countries, China's is only in the initial stage. Although China has abundant natural gas resources, the current domestic supply does not meet the ever growing demand of the Chinese natural gas market. Experts predict the demand gap will be bigger in the future.

When the gas shortage problem breaks out, resident users' daily lives will be affected; industry users may be forced to suspend production. The energy gap could result in the arrested development of economics. In consequence, the natural gas demand gap needs to be solved. If the Chinese government desires to cope with the problem, a lot of research 
has to be done on the Chinese natural gas market. This paper will focus on analyzing what causes the domestic demand-supply gap in the Chinese natural gas market and how to solve the shortage problem.

In this paper, the first part is an introduction. The question that needs to be addressed will be pointed out: what causes the demand gap and how to solve it. At the same time, the reason to choose this topic and some results of this problem will be described. The second part is the literature review. Some important opinions of the literature will be explained and analyzed; the relationship between opinions from these papers and the main idea of this thesis will be discussed. A discussion about the literature can be found here. The third part is background. The total energy use in China needs to be introduced and the trend will be analyzed. The major kinds of energy will be compared. The fourth part is what causes the imbalance between supply and demand. About the demand, above all, why people prefer to use natural gas should be explained; then demand changes in recent years will be analyzed. As to the supply, the major producing areas at present and some pipelines will be listed; recent supplies changes will also be discussed. After that, why imports can't fulfill the gap will be explained. Based on the market information, what causes the imbalance can be discussed. The shortage problem in the future will be forecasted then. According to two models, the future consumption and production of natural gas in China can be predicted and compared. The fifth part is how to solve the problem. Unconventional gas and natural gas storage are two possible approaches in the short term. Related policies will be introduced. Over time, China should reform the present natural gas pricing system. In the conclusion, all the findings will be summarized. 


\section{Chapter 2: Literature Review}

Natural gas use started late in China so it's an emerging industry. Articles about this topic are limited. However, several valuable papers are still available. Next are some of the papers that were useful for this thesis.

The topic of this paper is about natural gas because among all the energies in common use, natural gas is the cleaner. In "Energy and Environment in China-opportunity and challenge analysis during China $12^{\text {th }}$ FYP” written by Li Junfeng, the total energy used and its impacts on the environment is discussed. The author first looks at total energy consumption and production in the past decades. The most important part for this thesis is the consumption structure he analyses and he shows how the use of different kinds of energy changes. In comparison, natural gas accounts for $4 \%$ of the total consumption. Li's paper focuses on illustrating the relationship between energy use and the environment. Since combustion of fuel can release gas emissions that may pollute the air, natural gas and renewable energy are the cleanest sources. This explains why people choose natural gas.

Since this paper focuses on the natural gas demand gap, some basic market information needs to be known. "Natural Gas in China: Market evolution and Strategy", was written by Nobuyuki Higashi, and was a comprehensive introduction to the Chinese natural gas market. The author explains the market structure from four aspects: gas reserves, gas infrastructure, policy and regulation and gas industry, and then analyzes the demand and supply, not only based on past data but also on the future projections. Higashi describes the current price regime, points out the recent challenges and expresses his opinions 
about the price reform. About the gas security, measures for both short-term and long term supply disruptions are given. At the end, he discusses the possibility of a Shanghai Hub. Shanghai Hub in China will be like Henry Hub in United States. Natural gas futures contract is based on the amount of pipeline transportation in Henry Hub. This kind of contract set the primary price for the North American natural gas market.

Higashi's paper analyses the Chinese natural gas market in detail and gives the main inspiration for this thesis. Different from his paper, price reform will be discussed because it's a hot topic recently and it's also a problem that needs to be solved. As to the Shanghai hub, it's really a bold and creative idea. But although Shanghai is already a cosmopolitan city, natural gas in China is not a mainstream energy, it's too early to establish a hub there.

To help solve the demand gap problem, the present pricing mechanism needs to be known. Li, Tan and Wang introduce the pricing structure in "The Market Structure and Pricing of China's Natural Gas Industry". They use graphs to show the present method and what they design for the future. First, two drawbacks of the present mechanism are discussed. Then, they propose the "Main Design Ideas: Break apart upstream and midstream and bring competition to the upstream market". For the upstream and downstream, competition is emphasized, while the midstream needs monitored. Their design proves that natural gas pricing in China is problematic and provides me some inspiration about how to conduct pricing reform. 


\section{Chapter 3: Background}

In the world today, energy security is not a problem that concerns a single country but concerns the whole world. It is not only an economic problem, but also a political and military problem. Since reforming and opening up, China's energy demand has kept rising along with economic development. Right now, China is in a new growth cycle that is based on heavy chemical industries, leading industries that stimulate economic growth like automobiles, manufacturing and real estate that expand energy demand.

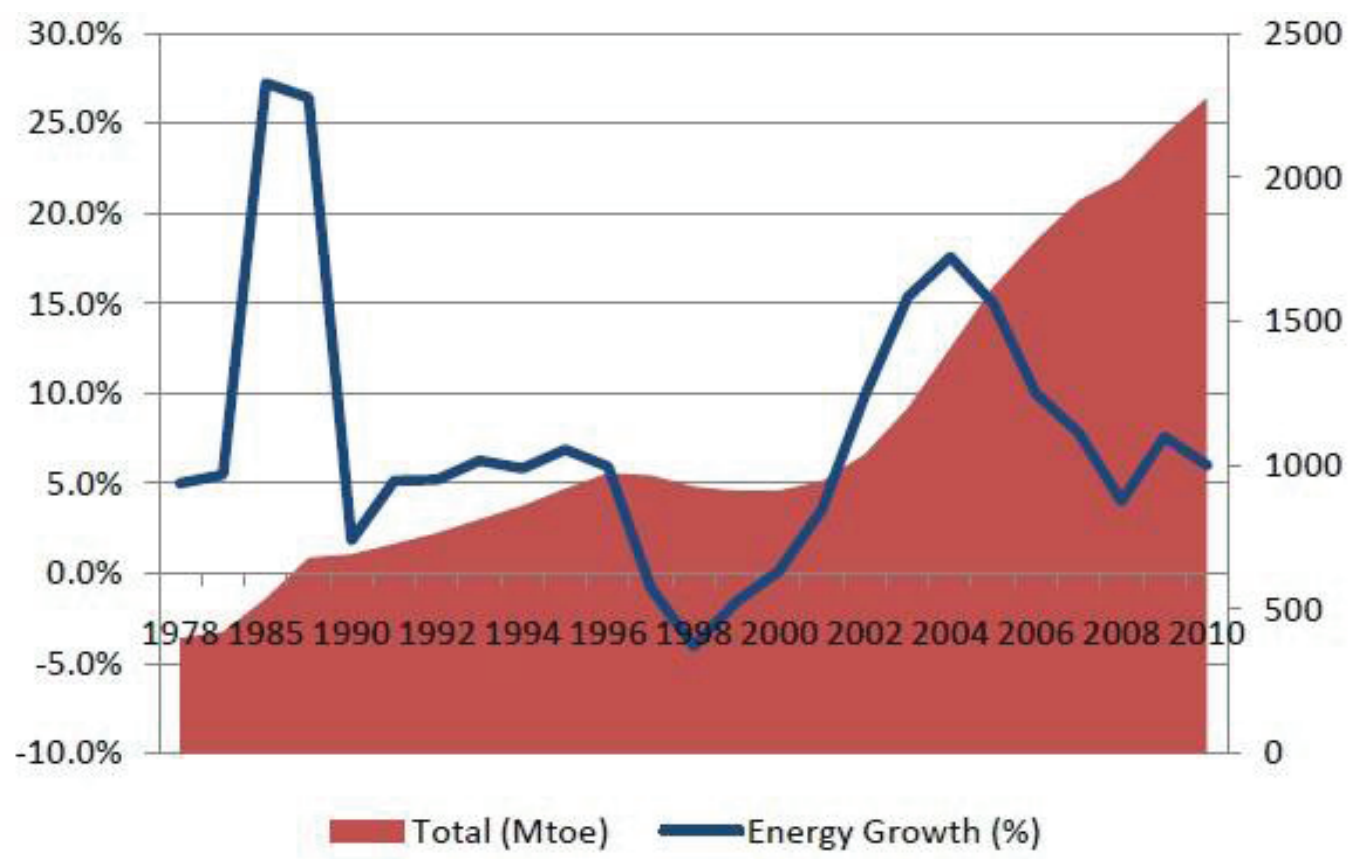

Figure 1 Total energy use and its grow th rate in China

Source: China Statistics Annual Report 2010

Figure 1 shows the total energy use and its growth rate in China from 1978 to 2010. Before 2000, energy consumption increased steadily although the growth rate fluctuates; after that, demand grew rapidly. In 2010, the total consumption reached 2275 million tons of oil equivalents (toe), nearly fourfold of that of 1978 (Junfeng Li, 2011). In addition, it 
is noticed that after experiencing the finance crisis (1998 \& 2008), the government gave incentives to maintain the GDP growth, and the growth rate rose in that period.

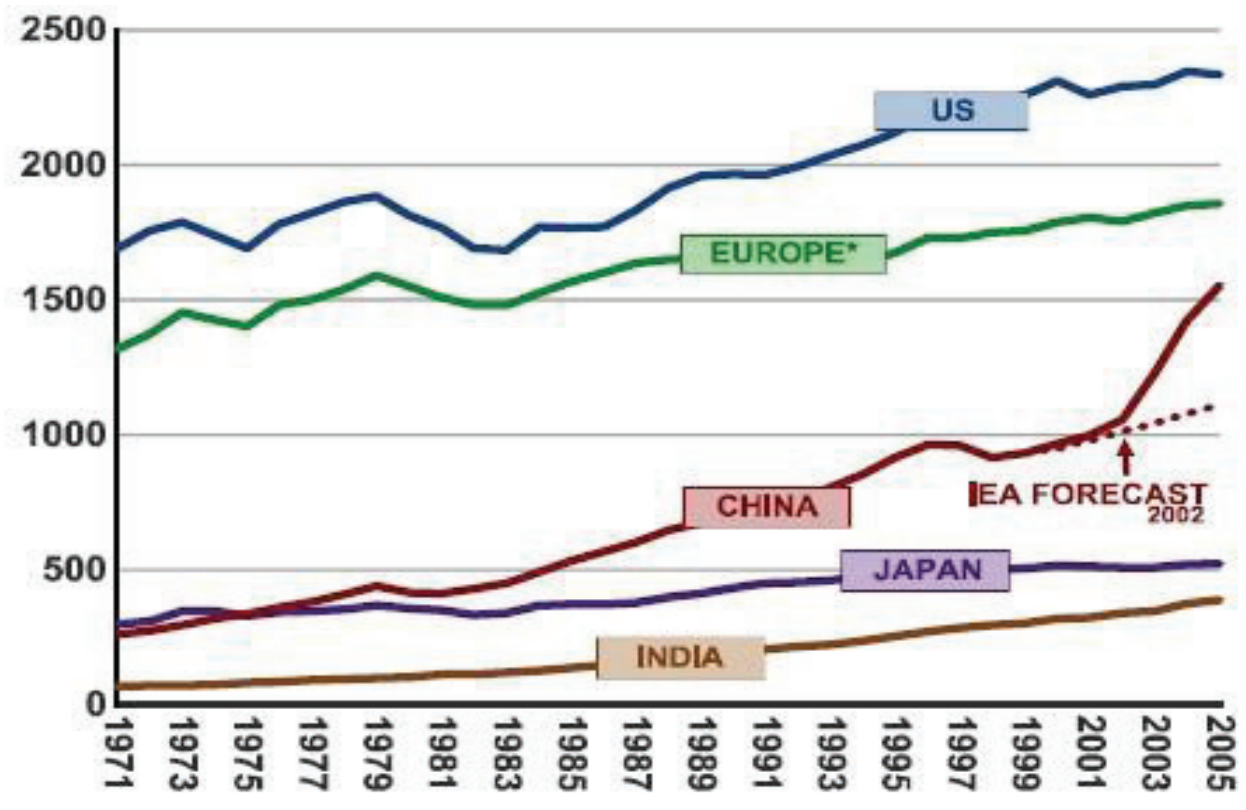

Figure 2 Energy use in five economic entities

Source: BP statistical Yearbook Unit (mtoe)

Comparing against other economic entities can help us find out what happened in China in the past. To some extent, GDP is able to reflect a country's development. In Figure 2, there are three typical developed countries and regions, and two developing countries. The lines indicate their energy demands from 1971 to 2005. It's worth nothing that China was far above the IEA forecast; even Chinese government first predicted the growth rate would be 3 to 4 percent (Daniel H. Rosen, 2007). But because of the rapid GDP growth, energy consumption rose much more. Actually, when China surpassed Japan and became the second largest economy in the world, it consumed more energy than what we 
expected. In 2011, China consumed 2613.2 mtoe with an $8.8 \%$ growth rate to 2010; USA consumed 2269.3 mtoe with a $-0.4 \%$ rate of increase (BP, 2012).

China is the developing second largest energy consumer in the whole world, but at the same time the amount of natural resources per capita is low because it is also the most populous nation. In the "Country Analysis Briefs: China" (2010), the author explains that China produces and consumes the largest amount of coal in the world. Except the United States, China is the largest oil consumer. For natural gas, although the consumption is still small, its usage has increased rapidly recently. The use of electricity also doubled since 2000; other renewable energy are temporarily in the initial stage in China.

Table 1 Proportions of four main energy used in China

\begin{tabular}{c|ccccc}
\hline Year & Total (Mtoe) & Coal (\%) & Oil (\%) & Natural gas (\%) & Hydro and others (\%) \\
\hline 2000 & 912 & 66.1 & 24.6 & 2.5 & 6.8 \\
2001 & 944 & 65.3 & 24.3 & 2.7 & 7.7 \\
2002 & 1038 & 65.6 & 24 & 2.6 & 7.8 \\
2003 & 1197 & 67.6 & 22.7 & 2.7 & 7 \\
2004 & 1407 & 67.7 & 22.7 & 2.6 & 7 \\
2005 & 1618 & 68.7 & 21.6 & 2.7 & 7 \\
2006 & 1779 & 69.4 & 20.4 & 3 & 7.2 \\
2007 & 1918 & 69.5 & 19.6 & 3.4 & 7.5 \\
2008 & 1995 & 70.2 & 18 & 3.6 & 8.1 \\
2009 & 2146 & 70.3 & 18 & 3.9 & 7.8 \\
2010 & 2275 & 68.3 & 19.2 & 4.3 & 8.2 \\
\hline
\end{tabular}

Source: China Statistics Annual Report 2010

The consumption structure has changed. Table 1 explains the proportions of four kinds of energy that are used in China from 2000 to 2010. Coal just as we discuss above, makes up a high proportion and keeps increasing. The good news is consumption declined in 
2010. Although the use of oil is still popular, there are too many uncertainties and the proportion has fallen. Since 2004, natural gas accounts for more and more of the total energy used. Hydro and sources that are emerging in China fluctuate over these years.

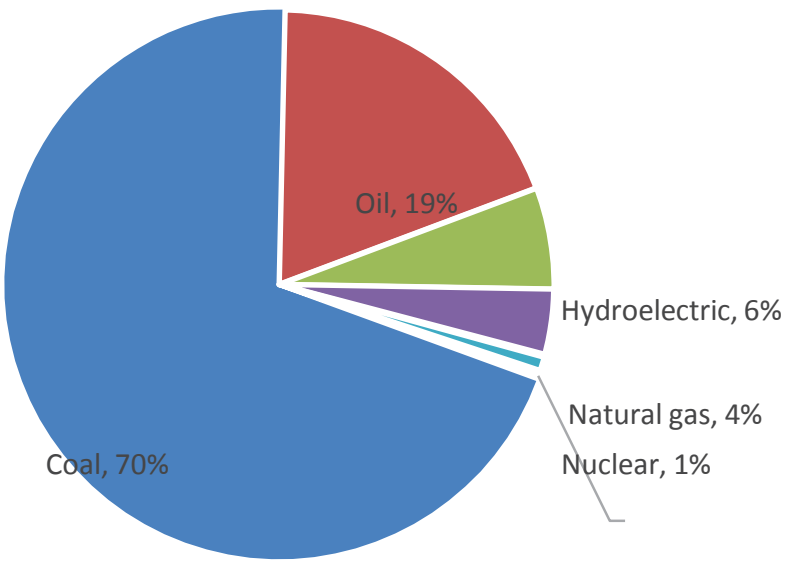

Other renerables, $0.30 \%$

Figure 3 Total energy consumption by Type (China)

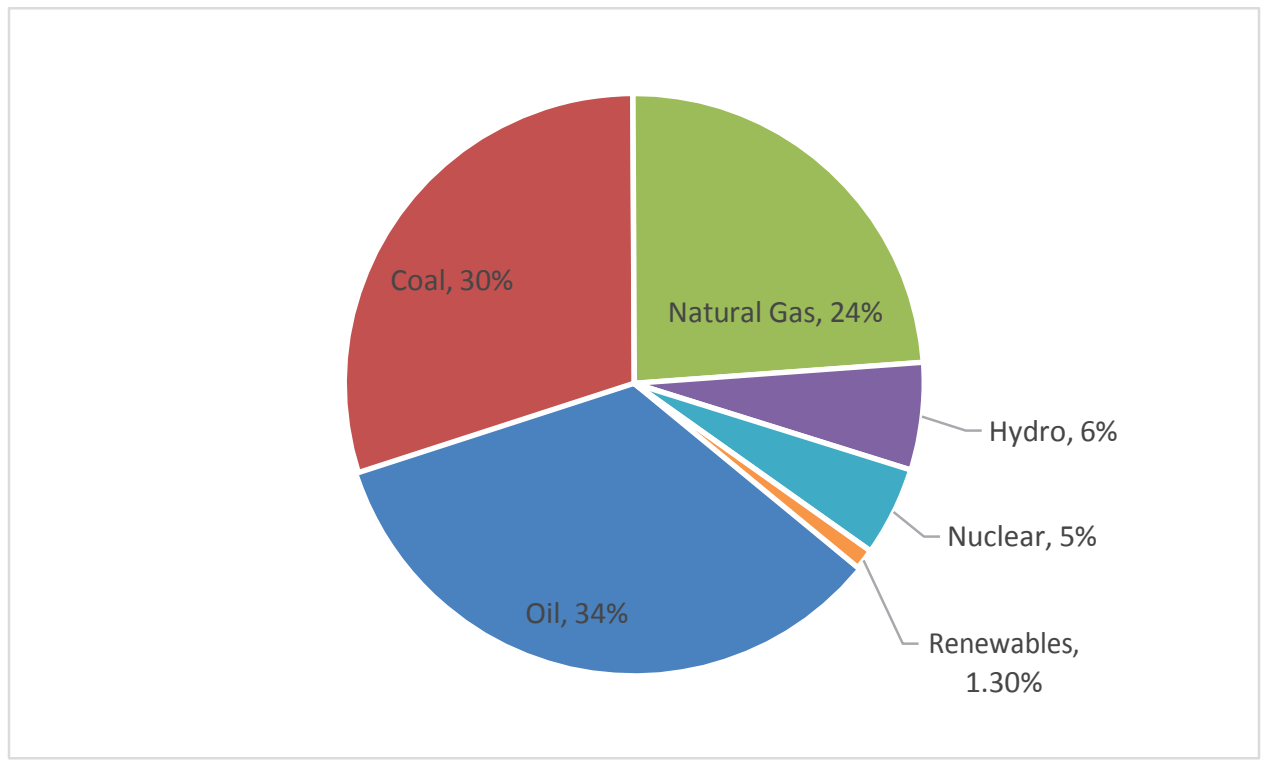

Figure 4 Total energy consumption by type (World)

Source: BP Statistics Review 
The specific numbers can be found from the above graphs. The two graphs show the total energy consumption by type, one is for China and the other is for the world. "Coal supplied the vast majority (70 percent) of China's total energy consumption of 90 quadrillion British thermal units (Btu) in 2009. Oil is the second-largest source, accounting for 19 percent of the country's total energy consumption. While China has made an effort to diversify its energy supplies, hydroelectric sources (6 percent), natural gas ( 4 percent), nuclear power ( 1 percent $)$, and other renewables ( 0.3 percent $)$ account for relatively small amounts of China's energy consumption mix.” (EIA, 2012) China uses so much coal because the reserves are rich and coal is cheaper than other resources. However, coal does have great negative effects on the environment. Comparing these two graphs, the usage of natural gas in China is far behind that of the world average level. Although some Chinese government efforts have been made to try to change the present situation, there is a long way to catch up with the world standard level based on current national conditions. 


\section{Chapter 4: What caused the shortage problem?}

At the beginning of this paper, it is discussed that in the near future natural gas use in China will far exceed domestic production; even now China manages the equilibrium with an effort. So why is it happening? It is best to analyze this problem from three aspects: supply, demand and imports.

\subsection{Demand}

Natural gas in China is considered as a promising energy source by more and more people not only because it is clean and safe, but also cost effective. The economists pursue profit maximization; in daily lives, what common people are most concerned with is spending less and at the same time getting more. Therefore, China is able to be the potential largest consumer of natural gas in the near future.

China has a long history of natural gas exploration and production. According to "Shih Chi”, by the third century BC, natural gas was found when digging irrigation well, which the farmer used it for cooking, transported it by bamboo pipes. Before liberation, China only had three small-scale gas fields and output of 10 million cubic meters per year. Now, the production in 2010 is nearly 100 billion cubic meters (John J. Carroll).

In China, the common applications of natural gas are: (1)Power Generation. Clean energy is able to reduce air pollution and alleviate energy shortages; Chemical Industry. Natural gas is the best raw material for producing nitrogenous fertilizer; (3) Urban Gas. Especially for cooking, city residents prefer this kind of fuel; (4) Liquefied Natural Gas 
Vehicle. The new type costs less than using gasoline and is green. So far, Chemical Industry and Urban Gas are the two primary applications.

\subsubsection{Why people choose natural gas?}

In the $19^{\text {th }}$ century, coal was the main energy source; in the $20^{\text {th }}$ century, oil replaced coal; in the 21 st century, most energy experts think it will be the era of natural gas. Why do they consider natural gas as the most promising future energy?

The natural gas accounts for nearly a quarter of the total energy consumption in the world. As a relatively new resource, how can it occupy such an important position? There are four advantages of this kind of energy.

I.Safe: Methane is the key component of the natural gas, which is relatively safe. On the contrary, the artificial coal gas contains noxious gas such as carbon monoxide. Once it leaks, it can do harm to human health. Besides, natural gas's ignition point is higher than that of liquefied petroleum gas (LPG); it is relatively harder to burn.

II.Economic: Because in the different districts of China, the prices are different. Take Shanghai that is one of the most developed cities as an example. In Shanghai, according to the data from Sinopec, the price of natural gas for the resident use is 2.2 yuan per cubic meter; liquefied petroleum gas's price is more than 16 yuan per cubic meter. Considering that natural gas's calorific value is 9500 kilocalorie per cubic meter while the calorific value of LPG is 25600 kilocalorie per cubic meter. This means to create 1000 kilocalories of heat, using natural gas costs 0.232 yuan, but using LPG it costs 0.625 yuan. Figure 5 reveals the prices of oil, electricity, natural gas and coal from 1990 to 2008. First, all the 
prices continued to grow because price level changes. Second, electricity seems the cheapest among the four kind of energy. But in fact, we lack electricity sometimes, especially in the summer. In the USA, people use electricity for cooking, while in China only a few people do this. Chinese people are used to LPG. Now more and more people are turning to natural gas because of the construction of pipelines and the resulting cheaper price. Third, according to this figure, oil and coal are obviously more expensive than the others in recent years.

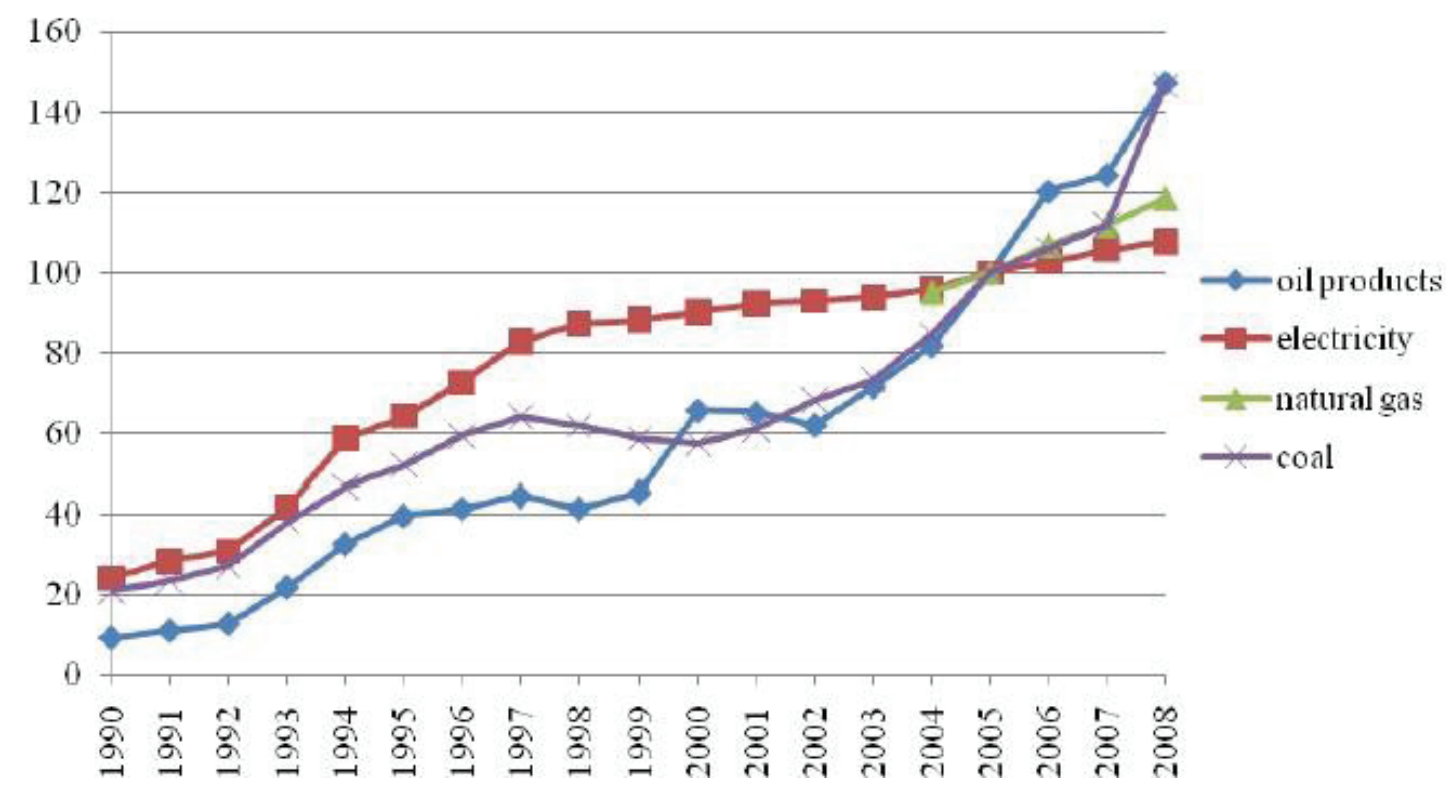

Figure 5 Four kinds of energies' prices

\section{Source:IEA}

I. Guaranteed: In accordance with current international practice, the supply contract of natural gas follows the take or pay clause over 25 years. Generally speaking, this contract sets the price ceiling and floor; the contract period is ordinarily a little long. Thus, people using natural gas are able to avoid the price fluctuations seen in the international petroleum market. Moreover, the imbalance between the supply and demand of oil makes 
this energy has obvious political attributes. For example, in 1970s, the Organization of Petroleum Exporting Countries imposed an oil embargo against the western countries, which led to a sudden increase in the oil price. The Persian Gulf crisis and the Iraq war also affected the oil price. So far, natural gas has not seen the same price fluctuation internationally.

N.Environment: In the $21^{\text {st }}$ century, in order to deal with the relationship between development and environment, choosing clean energy is a key decision. China's $12^{\text {th }}$ Five-Year Plan focuses on clean energy and indicates the direction of energy development. Natural gas is the cleanest energy of all the fossil fuels. As we know, more and more people pay attention to the greenhouse effect during these years. The global temperature gets higher and higher because of the greenhouse effect that resulted from the emission of a huge amount of carbon dioxide. Modern industrial society burns too much coal, oil and also natural gas. These fuels can release a great quantity of greenhouse gases after burning. Natural gas, relatively speaking, causes less emission of carbon dioxide. Looking at Figure 6, it shows $\mathrm{CO}_{2}$ emissions by fuel type from 1971 to 2010 . In $2010,43 \%$ of the total emissions came from coal combustion, $36 \%$ came from oil and $20 \%$ from natural gas (IEA, 2012). It's apparent that natural gas releases much less greenhouse gas. 


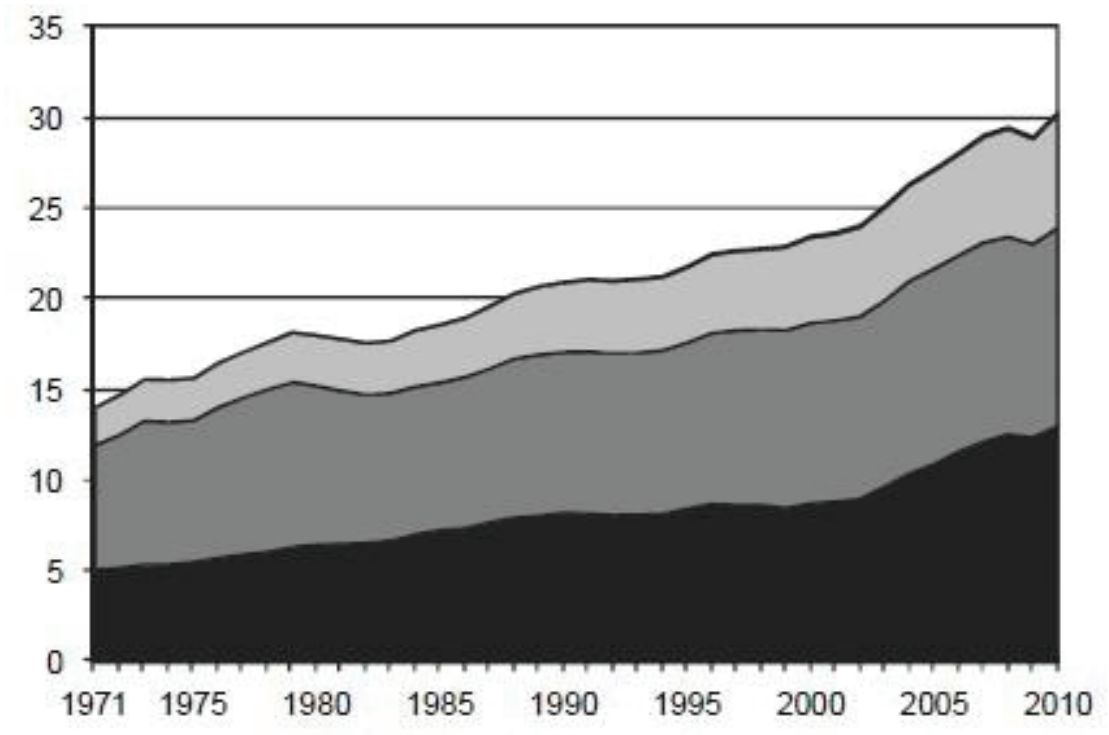

Coal and peat aOil a Natural gas $\square$ Other

Figure 6 CO2 emissions by fuels

Source: IEA 2012

Table 2 Fuels' emissions

\begin{tabular}{l|cccc}
\hline Fuel & $\mathrm{SO}_{2}{ }^{a}$ & $\mathrm{NO}_{x}$ & $\mathrm{TSP}^{b}$ & $\mathrm{CO}_{2}$ \\
\hline Pulverized Coal (PC) & 11 & 3 & 0.2 & 857 \\
PC w/ Wet Flue Gas Desulfurization & 1 & 3 & 0.2 & 893 \\
Integrated Gasification Combined-Cycle & 0.5 & 0.3 & 0.05 & 755 \\
Heavy Fuel Oil & 16 & 1.5 & 1.0 & 714 \\
Natural Gas Combined-Cycle & $\sim 0$ & 0.5 & .03 & 336 \\
\hline
\end{tabular}

a-Assumes 1.2 percent sulfur content.

b-Assumes fly ash removal efficiency of 99 percent. Solid waste of 74 grams $/ \mathrm{kWh}$ is also produced. Note: TSP = total suspended particulates;

Source: Derived by PNNL.

As a matter of fact, there are other noxious gases besides $\mathrm{CO}_{2}$. These harmful emissions cause 400,000 people premature deaths and at least $\$ 54$ billion loss each year (Jeffrey Logan, 1999). According to Table 2, several fuels' emissions in Chinese power plants are listed. In short, coal generates the most noxious gases and natural gas the least. Therefore, 
using more natural gas instead of coal and oil is beneficial for sustainable economic development.

\subsubsection{Demand Changes in past years}

The average growth rate of natural gas consumption has been above $20 \%$ since 2004 in China (Higashi, 2009). Rapid modernization, the development of pipeline network, the government environment policy and high oil price have all pulled up natural gas demand. Table 3 shows what happened during the years 2000-2010 in the Chinese natural gas industry. Natural gas consumption dropped in most countries in 2009 because of the global financial crisis while it still grew by $9.4 \%$ in China (Lin \& Wang, 2012). That shows the irresistible trend of the increasing demand of natural gas in the Chinese market.

Table 3 2000-2010 Gas consumption (Unit: Billion Cubic Meters)

\begin{tabular}{|c|c|c|c|c|c|c|c|c|c|c|c|}
\hline Year & 2000 & 2001 & 2002 & 2003 & 2004 & 2005 & 2006 & 2007 & 2008 & 2009 & 2010 \\
\hline Consumption & 24.5 & 27.4 & 29.2 & 33.9 & 39.7 & 46.8 & 56.1 & 70.5 & 81.3 & 89.5 & 109 \\
\hline
\end{tabular}

Source:Derived from CNPC

Generally, we divide natural gas demand into four parts: Industrial sector, Resident sector, Power sector and Transportation sector. Chemical/Fertilizer is the major consumer in the Industrial sector and accounts for the largest part of all gas consumption. The Resident sector is also a fast growing sector that follows the Industrial sector. Then the Power Sector takes only a small part of the total demand at present because generating power with natural gas is prohibited in some provinces by the related policy (as explained in Table 4). The Transportation sector also accounts for a small part. Although more and more buses and taxies in China now are using natural gas instead of gasoline, these public 
transportations are always waiting a long time to refuel. Besides, owners of private cars

prefer gasoline because gasoline can provide more power than natural gas.

The National Development and reform Commission (NDRC) proclaimed the Natural Gas

Use Policy that was put into practice on December $1^{\text {st }} 2012$. Actually, there was an older

version of this policy issued in 2007. The purpose of the new version is to guide and

formulate the use of natural gas in the downstream.

Table 4 Natural gas use policy

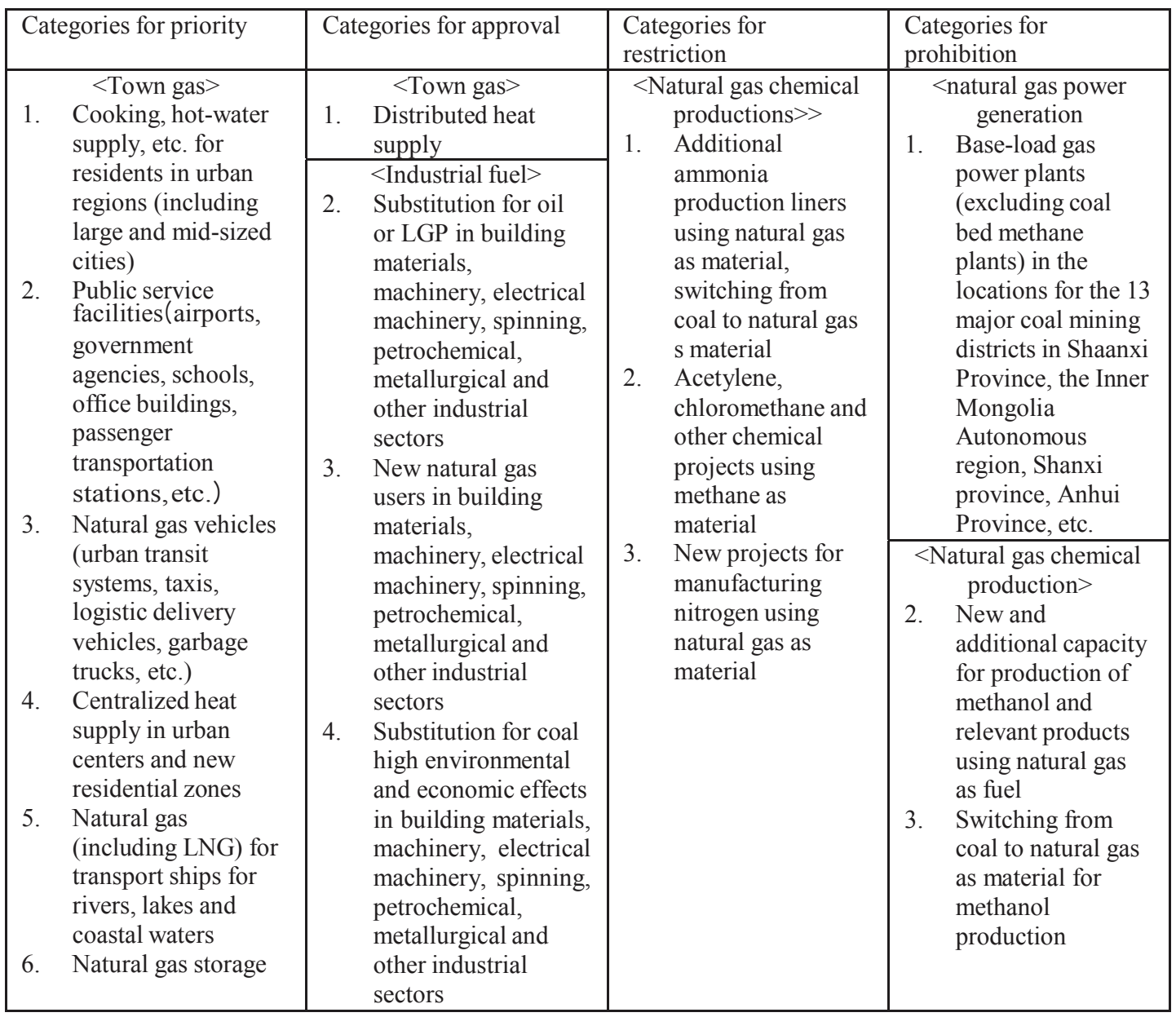




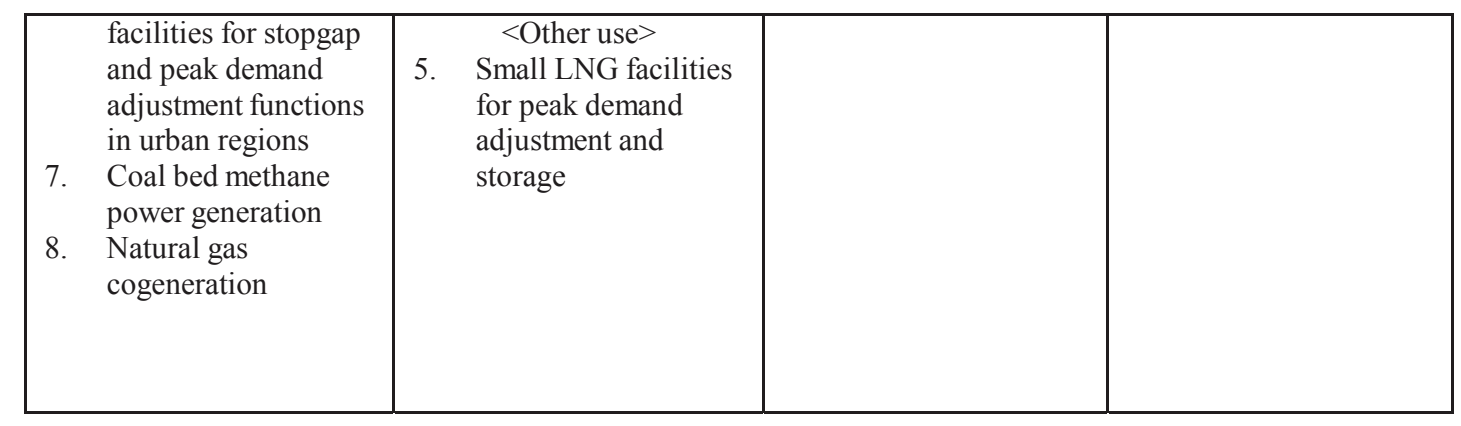

\section{Source:NDRC}

Table 4 expresses the main idea of 2012 Natural Gas Policy. The users are classified into four categories: Priority, Approval, Restriction and Prohibition. NDRC defines the order of these categories. From the table we can see that the government sets the demand of residents and public service as a first priority. So far, using natural gas to generate power is unrealistic in China because of the shortage problem. While China is rich in coal resources, coal is the cheapest source, so in coal mining districts using natural gas is unadvisable. It is noteworthy that the government encourages people to use natural gas for transportation. That represents the ambitions to reduce greenhouse gas emissions and the attitude to protect the environment.

\subsection{Supply}

\subsubsection{Reserves and Distributions}

China is one of the countries that first discovered and utilized natural gas in the world, but because of geographic and historical reasons, the development of the modern gas industry lagged behind other countries. Therefore, with the development of modern technology, there are reasons to believe that the natural gas market in China has great potential. 


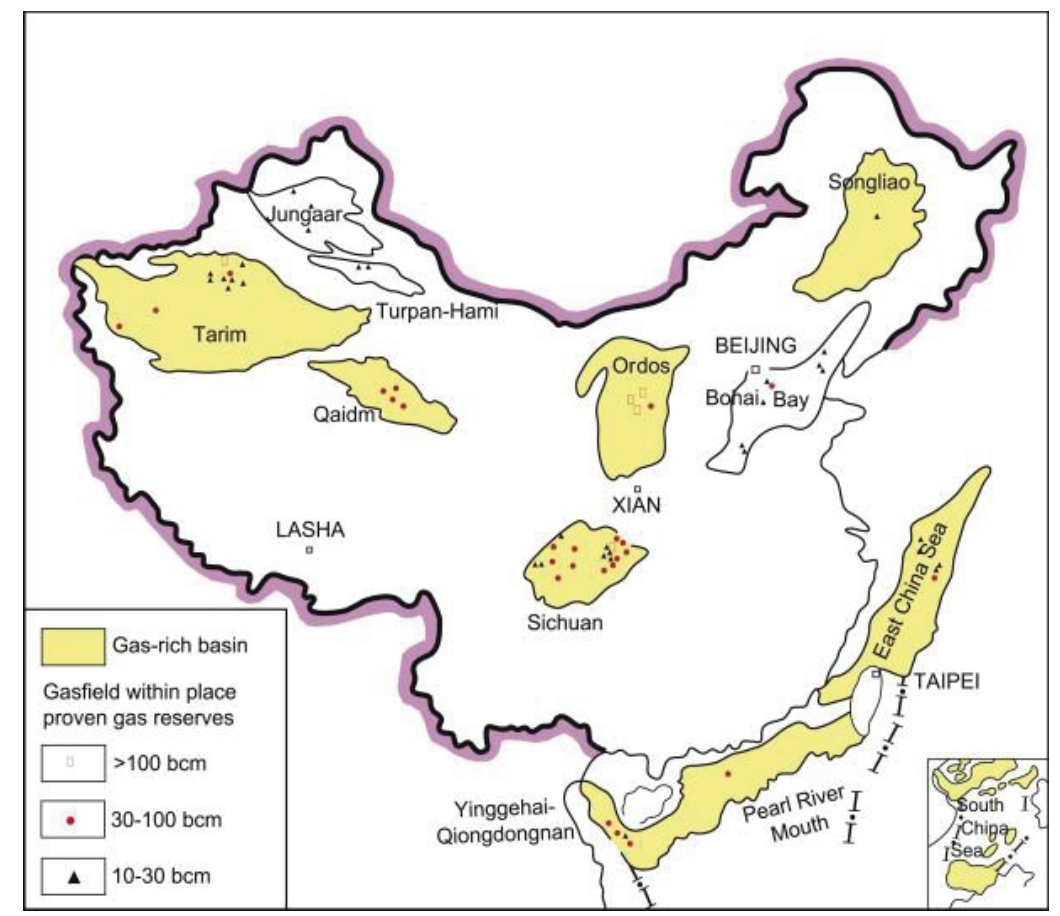

Figure 7 Distribution of natural gas in China

"Oil and Gas security: Emergency response of IEA Countries" (2012) estimates that China's natural gas reserve is up to 56 trillion cubic meters, and it has exploitable reserves of 22 trillion cubic meters according to the latest Evaluation of the Country on Oil and Gas Resources. The proven natural gas reserve in China is 5.9 tcm, while the United States' proven reserve is $8.5 \mathrm{tcm}$, and the Russia's is more than $30 \mathrm{tcm}$. Relatively speaking, China is not a country that is rich in natural gas, especially considering that China has an enormous population.

The distribution of natural gas in China is relative centralization; we can see the details in Figure 7. Gas is mainly distributed in the Tarim, Jungaar, Qaidm, Sichuan and Ordos basins in the west; the Bohai Bay, Songliao basins in the east; and the offshore areas like the East China Sea and Ying-Qiong basins. Table 5 below lists the nine basins and their 
reserves. Among them, Tarim, Sichuan and Ordos are the largest ones, especially Sichuan and Ordos; they both have reserves of over 1 trillion cubic meters.

Table 5 Natural gas reserves by basin

\begin{tabular}{|c|c|c|c|}
\hline Basin & $\begin{array}{c}\text { Proven } \\
\text { Reserves } \\
\text { (BCM) }\end{array}$ & $\begin{array}{c}\text { Number of Fields } \\
\text { with Reserves } \\
\text { Greater than 100 } \\
\text { BCM }\end{array}$ & $\begin{array}{c}\text { Number of Fields with } \\
\text { Reserves Between 10 } \\
\text { BCM and 100 BCM }\end{array}$ \\
\hline Junggar & 70 & 0 & 3 \\
\hline East China Sea & 120 & 0 & 5 \\
\hline Songliao & 200 & 1 & 1 \\
\hline Yingqionghai & 280 & 0 & 3 \\
\hline Qaidam & 290 & 0 & 4 \\
\hline Bohai Bay & 320 & 0 & 12 \\
\hline Tarima & 740 & 1 & 24 \\
\hline Sichuan & 1240 & 1 & 1 \\
\hline Ordos & 1610 & 6 & 61 \\
\hline Total & 4870 & 9 & 8 \\
\hline
\end{tabular}

Source: data from John J. Carrol

The Chinese western district is rich in natural gas resources; especially the Tarim which basin has abundant oil and gas resources. However, the demand for natural resources in the western district that is economically underdeveloped is not that great. Accordingly, this district is not able to make use of the resource advantages itself. In contrast, the eastern district in China that is short of natural resources is a main consumer. So the supply is in the west while the demand is in the east, which makes an imbalance. Based on this situation, the Chinese government started the west-east national gas transmission project. 
China has a 50-year history of building pipelines. The west-east gas pipeline required two stages. The first project started from Tarim basin in the west to Shanghai in the east; it is 4200 kilometers long and covers a lot of provinces in the middle of China. This pipeline was put into operation in December 2004 (Carroll). The second project also starts from Xinjiang province and runs to the southeast China. On December $30^{\text {th }} 2012$, the west-east II which was 9000 kilometers long was completed. Twenty eight provinces and Hong Kong benefit from this project. Furthermore, part of the west-east II even links with foreign countries. Natural gas imported from Central Asia plays an important role in improving the energy supply. In addition to the long nationwide west-east project, some regional pipelines also have been constructed during recent years. Table 6 shows related information on some major pipelines in China. 
Table 6 Main information about pipelines

\begin{tabular}{|c|c|c|c|c|c|c|}
\hline Pipeline & $\begin{array}{c}\text { Project } \\
\text { Dates }\end{array}$ & $\begin{array}{c}\text { Length } \\
(\mathrm{KM})\end{array}$ & $\begin{array}{c}\text { Diam. } \\
(\mathrm{mm})\end{array}$ & $\begin{array}{c}\text { Press } \\
(\mathrm{MPa})\end{array}$ & $\begin{array}{c}\text { Volume } \\
\left(10^{9} \mathrm{~m}^{3} / \mathrm{yr}\right)\end{array}$ & $\begin{array}{c}\text { Cost } \\
\left(10^{9}\right. \\
\text { yuan })\end{array}$ \\
\hline West-East \#1 & $2002-2004$ & 4200 & 1016 & 10 & 12 & 46 \\
\hline West-East \#2 & $2008-2011$ & 9000 & 1219 & 12 & 30 & 142 \\
\hline $\begin{array}{c}\text { Shannxi-Beijing } \\
\# 1\end{array}$ & 199101997 & 1256 & 660 & 6.4 & 3.6 & 6 \\
\hline $\begin{array}{c}\text { Shaanxi-Beijing } \\
\# 2\end{array}$ & $2004-2005$ & 932 & 1016 & 10 & 12 & 13 \\
\hline $\begin{array}{c}\text { Sichuan- } \\
\text { Shanghai }\end{array}$ & $2007-2010$ & 1700 & 1016 & 10 & 12 & 63 \\
\hline $\begin{array}{c}\text { Zhongxian- } \\
\text { Wuhan }\end{array}$ & $2001-2004$ & 738 & 711 & 6.4 & 3.0 & 5 \\
\hline $\begin{array}{c}\text { Lianzhou- } \\
\text { Yinchuan }\end{array}$ & $2006-2007$ & 469 & 610 & 10 & 3.5 & 1.9 \\
\hline $\begin{array}{c}\text { Guangzhou } \\
\text { Zhuhai- } \\
\text { Zhongshan }\end{array}$ & $2005-2007$ & 66 & 660 & 7.8 & 1.1 & 7.2 \\
\hline
\end{tabular}

Source: data from John J.Carroll

\subsubsection{Supply Changes in Past Years}

Based on China's domestic situation and the experience of other developed countries, the government plays an important role in the development of the scarce resources. In this regard, the China National Petroleum Corporation (CNPC), China Petrochemical Corporation (Sinopec group) and China National Offshore Oil Corporation (CNOOC), three totally state-owned companies dominate the Chinese gas market (Zhibin 2008). Some specific data on production can be found in Table 7. 
Table 7 Productions in three state-owned companies and total China (Unit: 100 Million Cubic Meters)

\begin{tabular}{|c|c|c|c|c|c|c|c|c|c|c|c|}
\hline Year: & 2000 & 2001 & 2002 & 2003 & 2004 & 2005 & 2006 & 2007 & 2008 & 2009 & 2010 \\
\hline \multicolumn{12}{|c|}{$\begin{array}{l}\text { Production of State-owned } \\
\text { Companies: }\end{array}$} \\
\hline CNPC & 18.3 & 20.6 & 22.5 & 24.9 & 28.7 & 36.7 & 44.2 & 54.2 & 61.7 & 68.3 & 72.5 \\
\hline Sinopec & 3.9 & 4.6 & 4.9 & 5.2 & 5.7 & 6.1 & 7.1 & 7.7 & 8.1 & 8.7 & 12.4 \\
\hline CNOOC & 4 & 3.9 & 3.7 & 3.3 & 4.9 & 5.1 & 6.2 & 6.7 & 7 & 7 & 10.2 \\
\hline \multicolumn{12}{|c|}{ Total Production of China: } \\
\hline & 27.2 & 30.3 & 32.7 & 35 & 41.5 & 49.3 & 58.6 & 69.2 & 80.3 & 85.3 & 96.8 \\
\hline
\end{tabular}

Source: 2010 Oil and Gas Report

Comparing this data with the total supply of the whole country, these three super companies account for as much as $98 \%$ in 2010 . At the same time, among the three companies, CNPC who is responsible for inland oil and gas holds about $75 \%$ of domestic gas reserves and $80 \%$ of the pipeline network (Higashi, 2009). In other words, the Chinese natural gas upstream and midstream are monopolized by these three state-owned companies. Lin and Wang (2012) point out that the natural gas production's average growth rate was $6.71 \%$ from 1980 to 2010 . What's more, during the recent years, this growth rate was $13.36 \%$ on average. It is noted that because of the Sichuan earthquake in 2008 , and Sichuan is a principal gas production province, the growth rate that year was relatively lower than those of other years.

\subsection{Gap and Import}

All in all, domestic production and consumption are rising rapidly. However, domestic supply is still not able to meet the demand. As a result, China began to import natural gas in 2006 and became a net importer in 2007. Imports have grown quickly since then 
(Snowden, 2012). In 2010, total net gas imports were 12.55 billion cubic meters with a degree of external dependence of $11.73 \%$ (Ministry of Commerce of China, 2011).

Table 8 2006-2010 Gas imports (Unit: Billion Cubic Meters)

\begin{tabular}{|c|l|l|l|l|l|}
\hline Year & 2006 & 2007 & 2008 & 2009 & 2010 \\
\hline Import & 0.96 & 4.1 & 3.6 & 11.2 & 12.55 \\
\hline
\end{tabular}

Source: Derived by CNPC

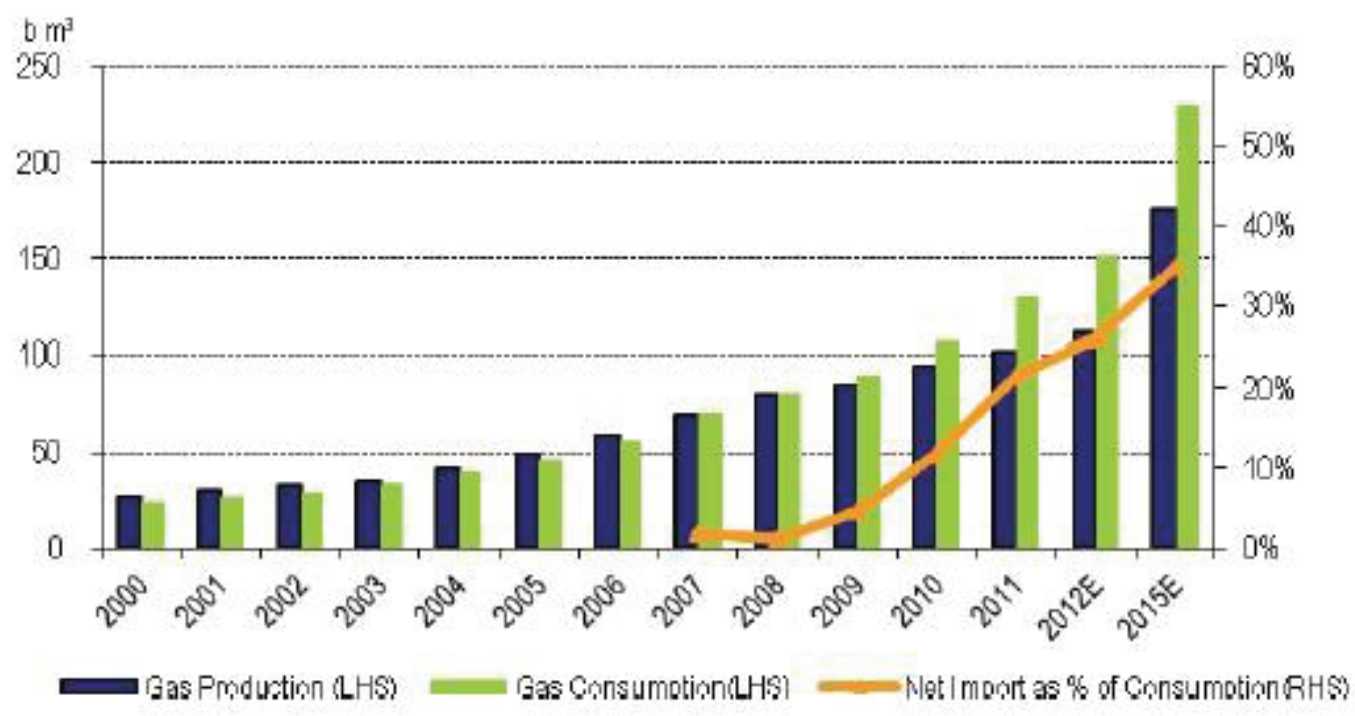

Figure 8 Production, consumption and import

Source: 12th five-year plan, NBS, BP

Snowden (2012) writes that China has signed a few sales and purchase agreements (SPAs) with countries, such as Turkmenistan, Kazakhstan and Australia. In addition, the latest news from The Wall Street Journal points out that China and Russia are making plans to create Energy Corporation. In this contract, imports could reach 38 billion cubic meters every year until 2018 (Marson, 2013). Now, about 30\% of the total imports come from 
Australia, 19\% from Qatar, 17\% from Indonesia, 13\% from Malaysia. Most of the other imports come from Asian and African countries.

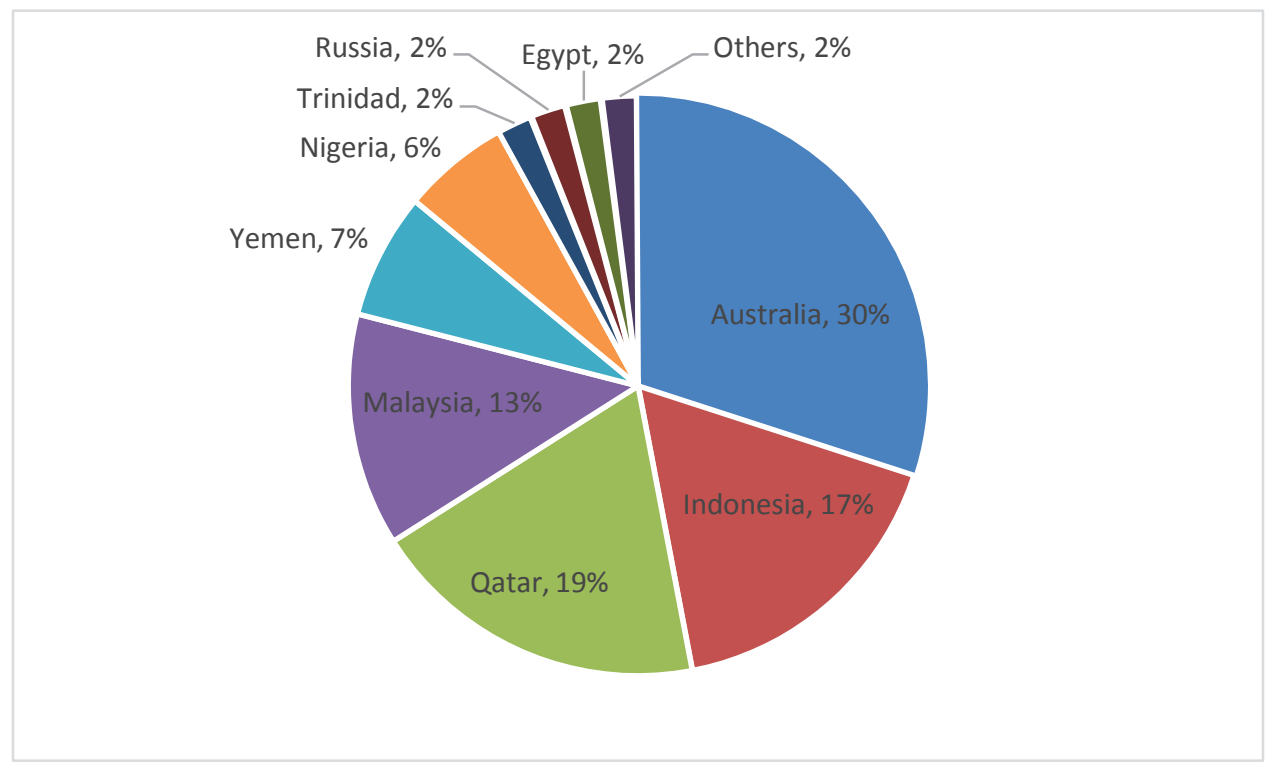

Figure 9 Natural gas import structure

Source: data from GIIGNL, UBS

Although China is able to attain more natural gas from external sources, we believe there is still a huge challenge to the Chinese natural gas industry. Imports involve too much uncertainty. For example, if China has conflicts with the above countries, they may break off the economic relations, and then the imports would be affected. Even if people ignore the uncertainties, imports are inadequate to meet the increasing gap between supply and demand in China. Later, some mathematical evidence will be shown.

\subsection{What caused the problem?}

In a free market, when the demand of some commodity is more than the supply, the price will go up until the demand equals to the supply; to the contrary, when the demand is less than the supply, the price will drop until the demand and the supply are the same. 
However, the Chinese natural gas market is not a free market, the government regulates the price. For example, if Chinese government sets gas price at $\mathrm{P}_{1}$ level, since the price is fixed, the demand will be $\mathrm{Q}_{2}$ and the supply will be $\mathrm{Q}_{1}$, a shortage occurs. The domestic demand and supply can't achieve a balance by the market itself.

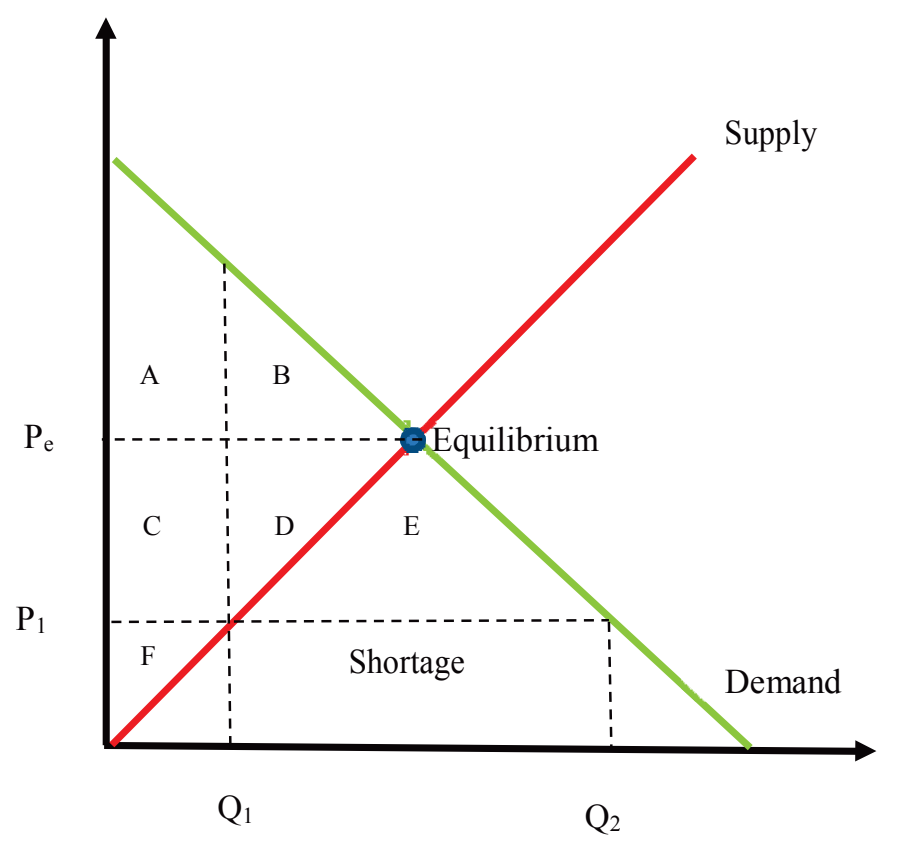

Figure 10 Demand - Supply Graph

At the equilibrium price level, the consumer surplus is $\mathrm{A}+\mathrm{B}$ and the producer surplus is $\mathrm{C}+\mathrm{D}+\mathrm{F}$. Without imports, at the regulated price level, the consumer surplus is $\mathrm{A}+\mathrm{C}$ and the producer surplus is only F. Therefore, the deadweight loss equals B + D. Stateowned companies import natural gas to meet the domestic demands currently. Considering the imports, the consumer surplus is $\mathrm{A}+\mathrm{B}+\mathrm{C}+\mathrm{D}+\mathrm{E}$ and the producer surplus is still $\mathrm{F}$ because the domestic production is only $\mathrm{Q}_{1}$. Therefore, although consumers gain a lot from regulated price, producers suffer a lot at the same time. To 
gain a deeper understanding of the imbalance between the demand and supply, the current Chinese pricing mechanism needs to be introduced.

At present, the total natural gas price in China is based on three parts: wellhead price, transportation cost and service fee. The government decides the final price on the basis of the production and supply cost; they also add a fair return. The NDRC (National Development and Reform Committee) sets down the wellhead price and the transportation cost; the local government sets down the service fee. With the development of a market oriented economy in China, the existing pricing mechanism for natural gas is not appropriate. The government takes control of every step in the natural gas industry, but the price management lags behind the development of the market. The price can't reflect the relationship between supply and demand.

Natural gas pricing in China experienced three periods. First period: State pricing (19571993). Before 1993, the price was completely controlled by the government. In order to encourage using natural gas that was a new kind of energy then, the price was only 30 yuan per cubic kilometer. But because exploration costs a lot and capital was insufficient, the government raised price three times during this period. Second period: State pricing and Government guide pricing (1993-2005). Thanks to the social transformation, the market played a more and more prominent role in pricing. The government set the planned natural gas wellhead price and guided the out-of -plan factory price. Suppliers could adjust the price within $10 \%$ of the guided price. The transportation fee was negotiated by suppliers and consumers. The service fee was set by suppliers once NDRC

approved it. Third period: Government guide pricing (2005 until now). At the end of 
2005, NDRC announced a critical measure. Chuanyu, Changqing, Qinghai, Xinjiang, Dagang, Liaohe and Zhongyuan gas fields called Grade I are guided by the government, suppliers and consumers can negotiate within $10 \%$ of the guided wellhead price. The price of natural gas from other gas fields called Grade II can also be revised, the upward fluctuation is $10 \%$ and there is no limit to the downward fluctuation. Their prices are set by state in 2005 are listed in Table 9.The government guided factory price is adjusted every year according to the average change of other fuels such as coal and oil.

Table 9 Government-Set gas prices

\begin{tabular}{|c|c|c|c|}
\hline & & $\begin{array}{l}\text { Government } \\
\text { set city gate } \\
\text { gas price } \\
\text { (RMB } / 1000 \mathrm{~cm})\end{array}$ & $\begin{array}{l}\text { Government } \\
\text { set city } \\
\text { gate gas } \\
\text { price } \\
\text { (\$/MMBtu) }\end{array}$ \\
\hline \multicolumn{4}{|l|}{ Grade I } \\
\hline \multirow{3}{*}{ Sichuan Chongaing } & City gas & & 3.03 \\
\hline & Fertilizer & $\hat{6} \overline{9} \hat{0}$ & 2.27 \\
\hline & Industrial & 875 & 2.88 \\
\hline \multirow{3}{*}{ Changqing } & City gas & 770 & 2.53 \\
\hline & Fertilizer & 710 & 2.34 \\
\hline & Industrial & 725 & 2.39 \\
\hline \multirow{3}{*}{ Qinghai } & City gas & 660 & 2.17 \\
\hline & Fertilizer & 660 & 2.17 \\
\hline & Industrial & 660 & 2.17 \\
\hline \multirow[t]{3}{*}{ Xinjing } & City gas & 560 & 1.84 \\
\hline & Fertilizer & 560 & 1.84 \\
\hline & Industrial & 585 & 1.93 \\
\hline \multirow{3}{*}{$\begin{array}{l}\text { Others (Daguang, } \\
\text { Liaoho, Zhongyuan) }\end{array}$} & City gas & 830 & 2.73 \\
\hline & Fertilizer & 660 & 2.17 \\
\hline & Industrial & 920 & 3.03 \\
\hline \multirow{3}{*}{ West East } & City gas & 1270 & 4.18 \\
\hline & Fertilizer & 1120 & 3.69 \\
\hline & Industrial & 1100 & 3.62 \\
\hline \multirow{3}{*}{$\begin{array}{l}\text { Grade II (Excluding } \\
\text { from Grade I) }\end{array}$} & City gas & 980 & 3.22 \\
\hline & Fertilizer & 980 & 3.22 \\
\hline & Industrial & 980 & 3.22 \\
\hline
\end{tabular}




\section{Source: NDRC}

State pricing makes sense to control a monopoly. As is well known, the upstream of natural gas industry is monopolized by CNPC, Sinopec and CNOOC. The government guided pricing is to protect people from high prices and make sure the price stays at a reasonable level over the long run. Besides, these three companies cannot attain surplus value excessively. Figure 11 shows the current pricing mechanism as discussed here. The upstream producing and the midstream transportation is controlled by NDRC, the downstream is controlled by local government.

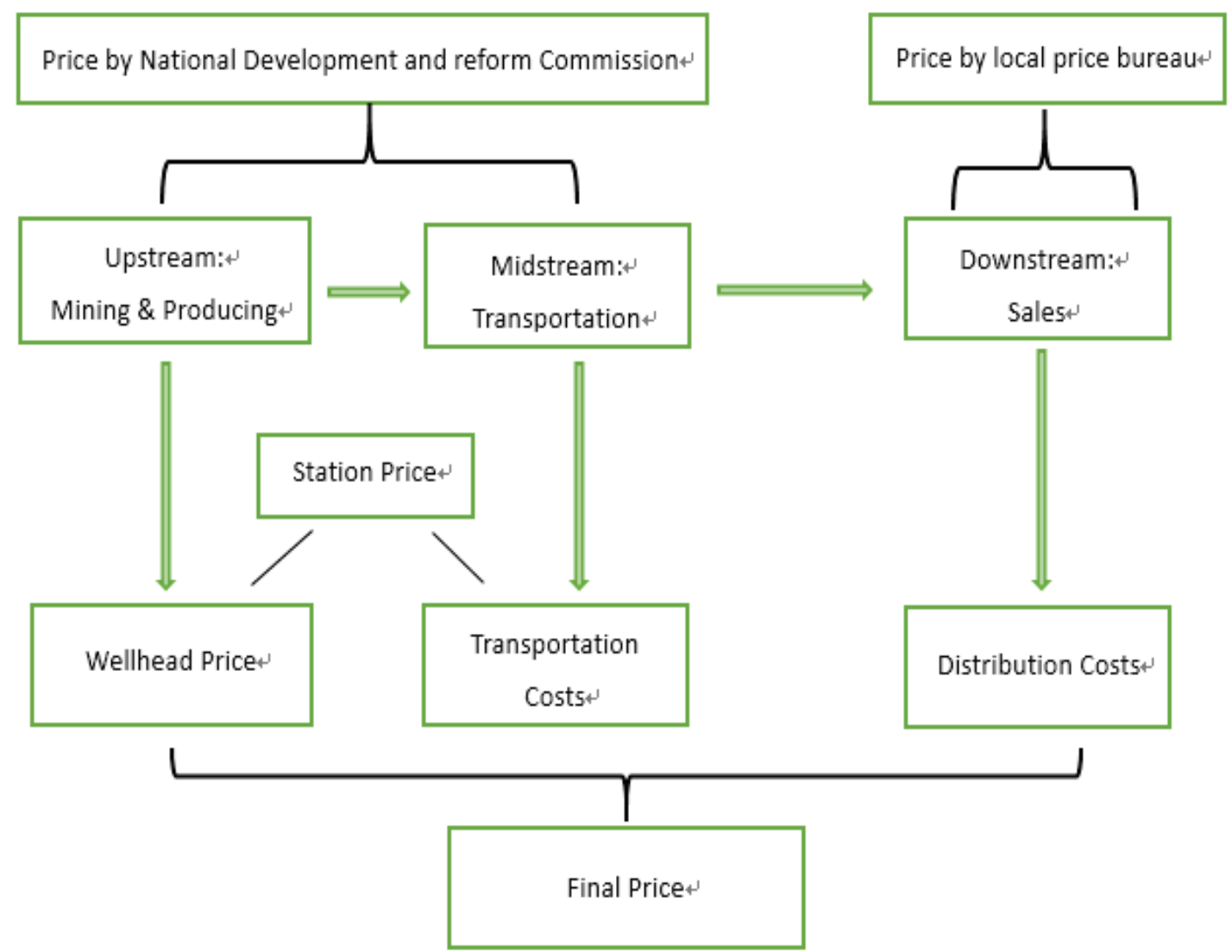

Figure 11 Present pricing mechanism in China

Reviewing the development of the Chinese natural gas pricing mechanism, it is noted that government intervention has played an important role for a long time. The Chinese 
government sets the gas price at a relatively low level so as to encourage people to use this clean energy. However, with the same inputs, suppliers prefer to produce something that can bring higher returns. Compared with natural gas, other resources such as oil are obviously better investments because they can be sold for higher prices relative to costs. The gas suppliers, who can't make much profit because of the controlled low price, don't have enough incentive and funds for exploration and production. That's why China can't use more natural gas from domestic sources.

About the imports, the monopoly of the exporting countries restricts the Chinese bargaining power; the Chinese domestic natural gas price is lower than the import price. However, to keep a stable gas market, domestic gas and import gas are sold at the same price. That means the suppliers import natural gas at a relatively higher price but have to sell at the lower domestic price. Therefore, more imports mean more loss for the suppliers. Although CNPC, Sinopec and CNOOC are state-owned companies, they are also listed companies, they are responsible to the shareholders. Therefore, importing is impractical for larger quantities.

Customers are used to a low price which leads to an increasing demand. Suppliers who require more profits will not increase the supply. Imports are more expensive and less reliable. What is worse, the present natural gas pricing mechanism set by government control prevent the market from reaching equilibrium through Adam Smith's "invisible hand'. At present, the domestic supply is not equal to the domestic demand in the Chinese natural gas market. Although the supply is increasing fast, it can't catch up with the more rapidly rising demand. Expensive imports can't fill the gap between domestic 
demand and supply. Therefore, the demand gap occurs. Next, the projection of future supply, demand and imports of natural gas will be discussed.

\subsection{Forecasting on Demand and Supply}

The current situation for the Chinese natural gas demand, supply and imports was discussed earlier. The shortage problem is obvious. If the Chinese government does nothing about this, what will happen in the future? From this point of view, forecasts can be done to predict the future demand and supply of natural gas.

\subsubsection{Demand Model}

There are many different models to predict natural gas consumption across the world; however, it is difficult to establish an accurate model that includes all the factors that influence gas consumption. Junchen (2011) forecasted gas consumption by a system dynamic approach; in this way, the forecasts can be done with many interdependent factors. The system dynamics approach explores the causal relationships by building a model.

In Junchen's model, he divided Chinese natural gas consumptions into four categories: Primary Industry consumption (PIC); Secondary Industry consumption (SIC); Tertiary Industry consumption (TIC) and Residential consumption (RC). Since PIC is agriculture consumption and is negligible in China, PIC is excluded from the model. SIC, which refers to the chemical industry and power generation, is the largest consumption category. TIC contains transportation service and accounts for $7.2 \%$ of the total consumption in 2007. RC refers to city gas use and accounts for $19.7 \%$ of the total gas consumption in China. 


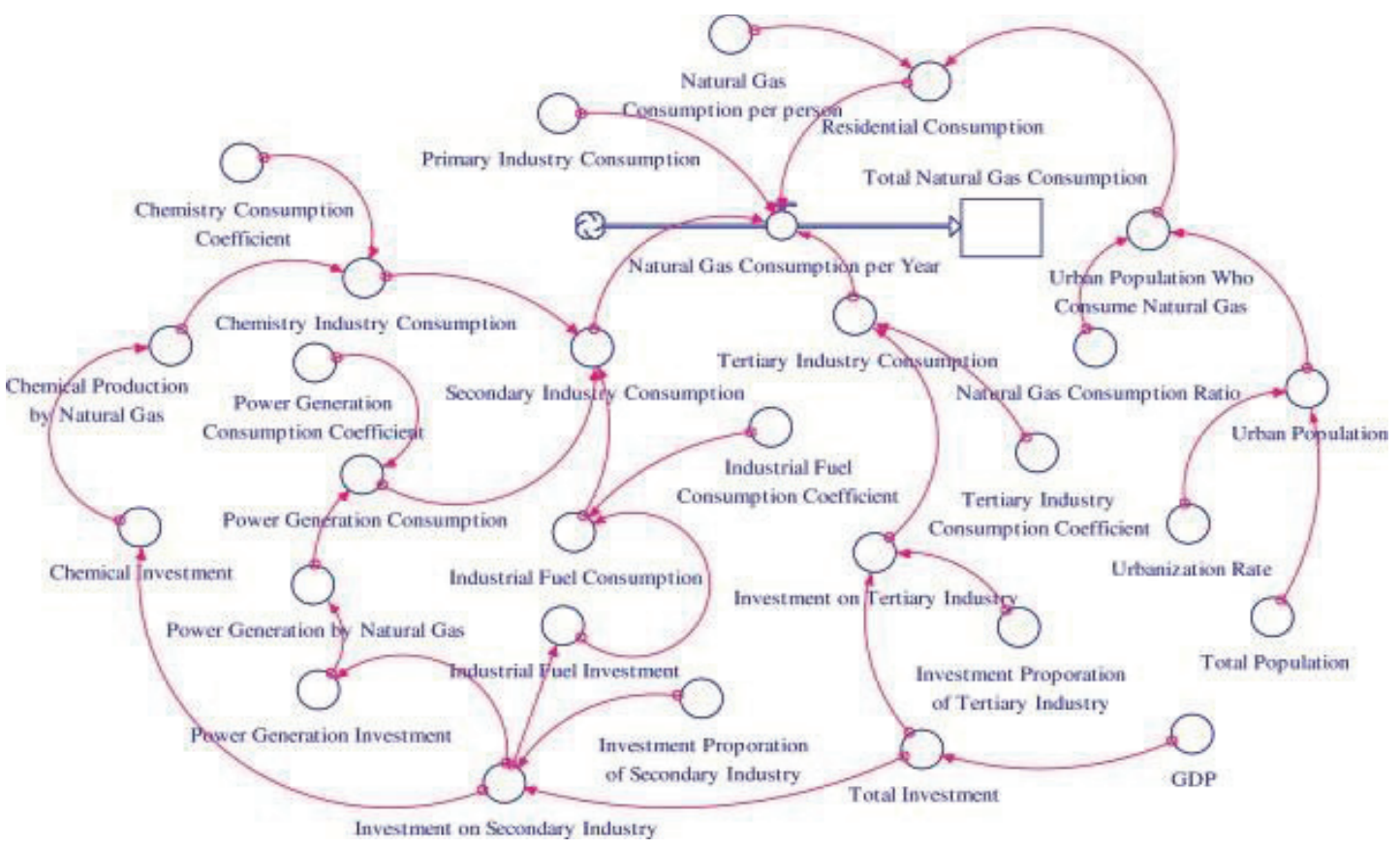

Figure 12 System dynamics model for China's natural gas consumption

Junchen used STELLA software to build the model. According to his model, investment determines the SIC and TIC; the total population determines the RC. The natural gas price is also an important factor. However, in China, under the current pricing mechanism, the gas price is relatively stable, so Junchen did not use the price for the forecast. In the Chinese natural gas industry, historical data proves that GDP has a close relationship with the investment, and Junchen used linear regression to describe the relationship. Therefore, GDP and the total population can be used to predict the future total consumption.

Junchen used the GDP data from the Development Research Center of the State Council. The investment can be calculated from the above method. Junchen assumed the investment proportions for SIC, TIC and RC to be constant in the future. The total population projection is taken from the National Population and Family Planning Commission. In this system dynamics model, the coefficient of SIC comes from the ratio 
of the historical Industry consumption to industrial production, TIC's coefficient is determined in the same way; Junchen assumed the RC's coefficient to be $33.9 \%$. The final consumption forecast in 2020 is $211.4 \mathrm{BCM}$.

\subsubsection{Supply Model}

As to the supply, there is an existing confirmed model. $<<$ China's natural gas: Resources, production and its impacts $>>$ that shows a classical and complicated model for production. The authors use the model to prove that China natural gas resources and productions are overestimated. The Hubbert logistic curve (1956) is successfully used to predict oil production and this model can be applied to estimate natural gas production too. Weng (1984) also developed a model that better fitted China's situations. Then Chen (1996) developed the Generalized Weng model which is the most widely used forecasting model in China. The Generalized Weng model has been proved to fit the reality of Chinese oil and gas productions (Wang et al, 2011). Therefore, it is chosen to predict the natural gas production. This famous model can be described as:

$$
\begin{aligned}
& n_{D}(t)=a t^{b} e^{-(t / c)} \\
& N_{R D}=a c^{b+1} \Gamma(b+1)
\end{aligned}
$$

"where $n_{D}(t)$ is proved geological reserves at time t, bcm/a; $N_{R D}$ is geological resources, bcm; $\mathrm{a}, \mathrm{b}$ and $\mathrm{c}$ are simply statistical parameters; $\Gamma(b+1)$ is the gamma function, where $\mathrm{b}$ is a positive, $\Gamma(b+1)=\mathrm{b}$ !.”

This model can be used to predict both reserves and productions. When forecasting productions, it should be changed to the following forms: 


$$
\begin{aligned}
& \mathrm{Q}(\mathrm{t})=\mathrm{a} t^{b} e^{-(t / c)} \\
& N_{R P}=a c^{b+1} \Gamma(b+1)
\end{aligned}
$$

"where $\mathrm{Q}(\mathrm{t})$ is gas production at time $\mathrm{t}, \mathrm{bcm} / \mathrm{a} ; N_{R P}$ is recoverable resource, bcm; other parameters are described above.”

To get the regression forms, a mathematical transformations needs be done to the above equations. Divide both sides by $t^{b}$, then take the logarithm, replace $\ln a$ with A, replace $\left(-\frac{1}{c}\right) t$ with $\mathrm{B}$, and we get equation (7).

$$
\begin{aligned}
& \frac{Q(t)}{t^{b}}=a e^{-(t / c)} \\
& \ln \frac{Q(t)}{t^{b}}=\ln a+\left(-\frac{1}{c}\right) t \\
& \ln \frac{Q(t)}{t^{b}}=A+B t
\end{aligned}
$$

Through liner regression, A and B can be calculated, that means a and c can be obtained, $\mathrm{b}$ is given by the goal seeking method. Thus, the gas production can be estimated according to equation (3).

The forecasted natural gas consumption in 2020 is 211.4 BCM, compared with the forecasted natural gas production of $148.8 \mathrm{BCM}$ from the Weng's model. The gap between the demand and supply will be $62.6 \mathrm{BCM}$. That means nearly $30 \%$ of the total consumption will depend on imports. Based on energy security, that huge gap is not acceptable.

Imports are an essential part of international trade, but being overly dependent on import, does not help normal economic development. There are too many uncertainties with imports, for example political incidents, natural disasters. Worse still, once the 
international pipelines are finished, when imports are not available because of some uncontrollable factor, it will cost a huge amount of money. Even though China has attained a few contracts with some neighboring countries, it does not guarantee the gas supply. The most important thing is that the import price is higher than the domestic price. Too many imports brings financial burden to the suppliers. Besides, the government has to give subsidies to the domestic consumers. Consequently, China can't depend on imports overly under the current pricing mechanism; they must take some other measures to deal with the increasing gap between gas supply and demand. 


\section{Chapter 5: Solutions and Suggestions}

According to the analysis and the forecasts in the earlier chapters, large inefficiencies exist in the Chinese natural gas market. Gas shortage will become a primary energy problem sooner or later. So what can China do to avoid these predictable troubles? When analyzing the natural gas market problem, supply and demand are estimated separately, and forecasts show an increasing gap. To solve the problem, increasing the supply and decreasing the demand are two possible ways. Because the government is encouraging the use of natural gas, demand may not decrease; therefore, in this paper, increasing the supply will be the main solution.

Experience from foreign mature markets tells us that government policies are important to the development of a natural gas industry. Sound policies can promote and guide the evolution of energy use. In China, the Five Year Plan is a part of the national economic plan; it sets goals for important construction projects and makes a plan for the proportion of economy. Traditionally, it's made every five years. The NDRC and NEA proclaimed the $12^{\text {th }}$ Five Year plan about natural gas in October 2012. The plan focuses on the infrastructure and takes both upstream and downstream into account. It also refers to unconventional gas. After analyzing the current situation of natural gas development in China and pointing out the main problem, some chief targets are:

(1) Reservations. Newly increased conventional gas reservations are $3.5 \mathrm{tcm}$ (exploitable reservations are $1.9 \mathrm{tcm}$ ). Newly increased Coalbed Methane reservations are $1 \mathrm{tcm}$. 
Domestic Productions. In 2015, the domestic supply should be about $176 \mathrm{bcm}$, including conventional gas $138.5 \mathrm{bcm}$, Coal-based Natural Gas $15-18 \mathrm{bcm}$, Coalbed Methane $16 \mathrm{bcm}$.

(3) Shale Gas. By 2015, shale gas reservation is $600 \mathrm{bcm}$, exploitable reservation is 200 $\mathrm{bcm}$ and production is $6.5 \mathrm{bcm}$.

(4) Imports. According to the contracts, imports each year should be $93.5 \mathrm{bcm}$.

(5) Infrastructure. During the Five Year Plan period, new pipelines length are 44 thousand kilometers, new capacity is $150 \mathrm{bcm}$ per year. New storage capacity is $22 \mathrm{bcm}$, accounting for $9 \%$ of the total consumption in 2015 . The emergency storage is $1.5 \mathrm{bcm}$.

(6) Popularizing Rate. Use of gas in cities and rural areas should reach 250 million, accounting for $18 \%$ of the total population.

Most of the targets are aimed to encourage an increase in the natural gas supply, including both domestic supply and imports. Two of the targets mention unconventional gas; it is just one of the solutions to the shortage problem. (China's 12th Five-Year Plan: Energy)

\subsection{Unconventional Gas}

Generally speaking, when people talk about natural gas, they mean conventional gas. However, with the boost to the natural gas industry, the use of unconventional gas has come into consideration in order to satisfy the needs of clean energy. Unconventional gas is a relative concept compared with conventional gas that has good reservoir property; it 
cannot be exploited by traditional techniques. In "What is the difference between Conventional and Unconventional Gas", these two kinds of natural gas are explained in details. "Conventional gas is gas that is trapped in structures in the rock that are caused by folding and/or faulting of sedimentary layers. There are a number of factors which need to be present for conventional gas accumulations, including:

Source: an organic rock which is composed of either marine or terrestrial organic debris that has been compacted by layers of overlying rocks over long periods of time and subsequently 'cooked' by the increased pressures and temperatures at depth to produce hydrocarbons.

Migration: these hydrocarbons are released into pores or spaces of the rock and when these spaces connect, the rock is termed permeable. Permeable rocks allow the migration of hydrocarbons to travel upwards towards lesser pressure until they reach a 'trap'.

Trap: is required to accumulate the hydrocarbons into a specific area so that a well can be drilled into the area and extract the hydrocarbons. A trap or seal is commonly a nonporous or impermeable layer of rock that will not allow the penetration of any gas or fluid. It is also commonly folded to form an umbrella shape or faulted to juxtapose rocks that will restrict any gas or fluid flow.

Reservoir: is the rock of high porosity and permeability that holds the hydrocarbons below the trap.

Unconventional gas does not require these geological characteristics. It is gas that is trapped in impermeable rock which cannot migrate to a trap and form a conventional gas 
deposit. Unconventional gas may be trapped in the source rock from which is generated or it has migrated to a formation of rock which has since become impermeable."

According to the XiWang Energy's report (2011), the reserve of conventional natural gas is 56 trillion cubic meters, while the unconventional gas's reserve is more than 150 trillion cubic meters in China. China National Petroleum Corp (CNPC) points out in 2012 the supply of unconventional gas is 44.5 billion cubic meters (Sarah, 2013). It is thus clear that unconventional gas is able to make up some of the natural gas shortage.

At present, Coalbed Methane, Coal-based Natural Gas, Coke oven gas to synthetic natural gas (SNG) and Shale gas are some relatively familiar unconventional gas sorces. Judging from the development, Coalbed Methane is the only one among those unconventional gases that has been put into operation currently and its output has grown very quickly during these years. China has an explored reserve of 1800 million cubic meters of Coalbed Methane, according to the Ministry of Land and Resources, and may consume up to 230 million cubic meters each year since 2020 (Pan and Zhou, 2010). Coalbed Methane can be used in fuel generation, industry fuel and residential fuel; it can even be liquefied to automobile fuel.

Coal-based Natural Gas is also popular. The Chinese government has issued related policies to orient this industry. China has abundant coal but a lack of oil and gas. CircumBohai-Sea, Yangtze River Delta and Pearl River Delta are three vigorous economic regions that need a great deal of natural gas. Inner Mongolia and Xinjiang province are rich in coal, but the transaction cost is very expensive. Therefore, turning coal into natural gas would be a creative strategic choice. 
Coke oven gas to SNG develops well in China, moreover the use efficiency increases obviously. Liquefied natural gas comprised of Coke oven gas not only makes use of resources reasonably, but also reduces environmental pollution caused by gas emissions. Energy conservation and emission reduction have come true, it has great market value. So far, China has respectable plans in this field.

Ordinarily, Shale gas's producing life can last 30 to 50 years; it is longer than that of conventional gas, and means huge economic value. And better yet, this unconventional gas is distributed broadly, and the reserves may be as high as 30 trillion cubic meters (Pan and Zhou, 2010). EIA predicted the recoverable reserves of shale gas in China are 36.1 trillion cubic meters, higher than 24.4 trillion cubic meters that are in the USA ("China awards two out of four shale gas blocks in first shale gas tender", 2011). However, in China, Shale gas which has great potential is developing slowly and still in its infancy. The technology lags behind other producers.

All in all, China has significant amounts of unconventional gas; they will play an important role in the next 10 to 20 years and become an indispensable part in the sustainable gas industry development. According to CNPC, unconventional gas may contribute nearly a quarter of China's total supply by 2030 (Sarah, 2013). In "China's Presence Grows in Unconventional Gas and Oil Markets" (2010), Saya Kitasei and Haibing Ma tell us that CNPC and Shell decided to explore the unconventional gas in Sichuan province in collaboration. The Chinese government welcomed the international investment. Learning from foreign experience and strengthening the technology is what China must do. 


\subsection{Natural Gas Storage}

Gas storage can adjust peak seasonally so it improves the reliability of the gas supply. As is known, natural gas demand in China is increasing rapidly. In order to ensure the domestic supply and avoid a gas shortage, the government has built storage tanks in recent years.

People often do not spend all their salaries but save a part of them in the bank, once they have an emergency they are able to withdraw the deposit. For the same reason, natural gas can be saved in storage. The consumption of natural gas varies in different seasons; usually we use much more in winter than in the summer because of the cold weather. For example in Beijing, people consume no more than 4 million cubic meters natural gas per day in summer, while they consumes more than 50 million cubic meters per day in winter (Han, 2010). To solve this common problem, people have to save natural gas just like money. Put the extra energy in storage, and when the supply is not enough, people can count on the "deposit".

Currently there are a few ways to meet the seasonal peak of natural gas use such as ground storage and LNG storage. Most people believe underground storage is the best way. The underground facilities are mainly constructed near downstream cities. In "Underground natural gas storage in the UK", compared with above ground storage, underground storage has a lot of advantages: first, the storage capacities are larger and cover more areas; second, although disposable investments are huge, they are durable in use and economical; third, it is obvious that underground storage is much safer. Take Sichuan as an example, it has abundant natural gas reserves. At the same time, Sichuan is 
also a province that suffered earthquake hazards frequently. The ground deformations and displacement are the major cause of earth quake damage to pipelines, stations and ground facilities. (Earthquake Hazard Reduction, 1992) To avoid and reduce the hazards from earthquakes, several things can be done. During the construction of the natural gas stations and ground facilities, technology that reduces earthquake affects should be taken. For example, buildings can be strengthened. The steel used to build pipelines should be selected. All of the underground facilities are located in very deep ground, considering the depth and the design of the system connecting the storage to the surface, the underground storages are very well protected. Therefore, in the case of serious earthquakes, the damages will be majorly on the ground which can be repaired with relatively low costs.

In a general way, there are five types of underground gas storage facilities. They are salt caverns, mines, aquifers, depleted reservoirs and hard-rock caverns.

Depleted reservoirs are the most widely used one due to it's availability; the difference between aquifers and salt caverns is their requirement about base gas, the former requires more base gas; abandoned mines were what people used before, on the contrary, hardrock caverns may be what we use in the future ("The Basics of Underground Natural Gas Storage", 2004).

Underground gas storage can not only fullfill the need during peak demand, it has more important values: emergency and strategic reserves. In warfare or natural disaster, the strategic significance will be obvious. For an instance, during the winter of 1999, there was a huge upsurge in the demand of natural gas in France because of the weather, 52\% 
of the total supply come from underground storage (Han, 2010).

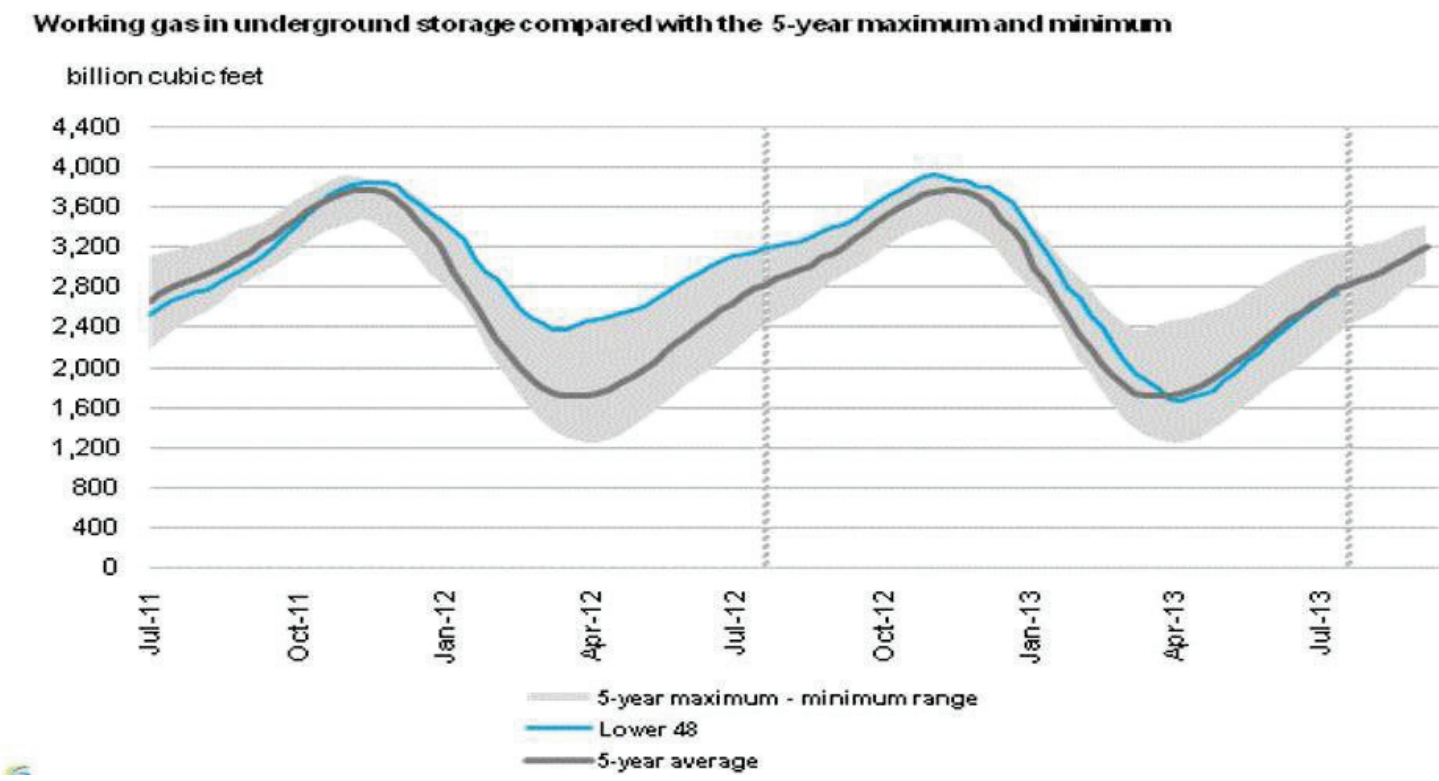

Figure 13 Working gas in underground storage compared with the 5-year maximum and minimum

Source: IEA

("Base gas (or cushion gas) is the volume of gas intended as permanent inventory in a storage reservoir to maintain adequate pressure and deliverability rates throughout the withdrawal season.Working gas capacity refers to total gas storage capacity minus base gas.’(EIA, 2004))

Developed countries have already been working on gas storage and have achieved good results. Taking the USA as an example, Figure 13 shows the storage volume from July 2011 to July 2013. The waves support the disscussion above, that is in the cold days people need and use more natural gas so the storage declines; when the weather warms up, natural gas will be saved and the storage increases. In fact, even in developing countries people are trying this approach. A proposed project costs about 2 billion dollars is running smoothly in Nigeria, and it's only a part of the whole Afican plan. 
China did not start research on underground gas storage until the 1970s and tried to construct relevant facilities in the 1990s in order to ensure the supply for the Beijing district. The only storage facility that has been completed by CNPC is in the Dagang oilfield (Yuwen Zhang, 2010). The reasons why China has developed slowly in this field include less-advanced technology and geological conditions in some district that are not appropriate. Eastern China is the main consumer, however, there is less gas pool there so it's hard to use depleted reservoirs. In southern China where local geological conditions are complicated, exploration is really difficult.

Underground gas storage concerns national energy and public safety, thus the government and CNPC are both working on it. In "Natural gas pipeline and storage projects in China: Expansions underway" (2010), the author says the J58 gas storage cluster in northern China with capacity of 750 million cubic meters was completed in 2010. Jintan and Liuzhuang are two storage facilities located in eastern China and are estimated to reach 2 billion cubic meters in 2020. According to the CNPC, 10 more storage facilities with 22.4 billion cubic meters capacity will be built during 2011 to 2015 .

\subsection{Pricing reform}

Price is the determining factor that influences people's willingness to buy something. The Chinese government keeps a relatively low price to encourage the use of natural gas. In the short term, if China invests more financial capital into the construction of natural gas storage facilities and uses more unconventional gas, the supply will rise and the shortage problem may be solved to some degree. But in the long run, market pricing is the necessary condition to the sustainable development of the natural gas industry. 


\subsubsection{The current pricing method's disadvantages}

The current pricing method is not able to adapt to the market economy developing in China. No matter what happens in the market, the price is relatively stable. However, the products using natural gas follow the market. For example, if the price of chemical fertilizer made from natural gas increases, the producer's profit increases because of the constant gas price. But the gas suppliers' profit will decrease because of the rising production cost. So the gas suppliers will lack incentive to produce more gas.

The use of natural gas has a seasonal character, less in the summer and more in the winter. The prices in market economy countries also have seasonal trends. According to the Chinese gas pricing mechanism, the factory price of gas is only adjusted one time each year; therefore, it cannot reflect the seasonal changes of the supply-demand relationship.

Last but not least, the current method really cannot show the relationship of natural gas with its substitutions. "In Brown and Yu"cel (2008), the relationship generated by competition with residual fuel oil at the burner tip is given as:

$$
P_{H H, t}=-0.25+(85 \% / 6.287) P_{W T I, t} .
$$

where $P H H, t$ is the price of natural gas at the Henry Hub, and $P_{w T I t}$ is the price of West Texas Intermediate crude oil at Cushing Oklahoma" (David J. Ramberg). They believe a tie does exist between oil and natural gas prices. Both oil and natural gas are made up of carbon and hydrogen, they are important fossil fuels. For transportation and resident use, natural gas is able to replace oil to some extent, their prices should be related. Although the Chinese government guides the oil pricing, the Chinese oil price is nearly in line with 
the international oil price. However, the domestic natural gas price is much lower than the international natural gas price. If the Chinese natural gas price is correctly linked to the oil price, the gap between the domestic natural gas price and international natural gas price will be reduced. Chinese guided pricing has a disadvantage in this regard.

\subsubsection{Comparisons of pricing mechanisms}

Before discussing how to carry out the reform of pricing, types of pricing mechanisms need to be discussed. Table 10 comes from a report of International Gas Union (IGU) in 2012. The definitions of Oil Price Escalation (OPE), Gas-on-Gas Competition (GOG), Bilateral Monopoly (BIM), Netback from Final Product (NET), Regulation: Cost of Service (RCS), Regulation: Social and Political (RSP), Regulation: Below Cost (RBC) and No Price (NP) can be found in this table.

Table 10 Main pricing mechanisms in the world

\begin{tabular}{|l|l|}
\hline $\begin{array}{l}\text { Oil Price escalation } \\
\text { (OPE) }\end{array}$ & $\begin{array}{l}\text { The price is linked, usually through a base price and an } \\
\text { escalation clause, to competing fuels, typically crude oil, gas } \\
\text { oil and/or fuel oil. In some cases coal prices can be used as can } \\
\text { electricity prices. }\end{array}$ \\
\hline $\begin{array}{l}\text { Gas-on-Gas } \\
\text { Competition(GOG) }\end{array}$ & $\begin{array}{l}\text { The price is determined by the interplay of supply and } \\
\text { demand-gas-on-gas competition-and is traded over a variety of } \\
\text { different periods (daily, monthly, annually or other periods). } \\
\text { Trading takes place at physical hubs (e.g. Henry Hub) or } \\
\text { notional hubs (e.g. NBP in the UK). There are likely to be } \\
\text { developed futures markets (NYMEX or ICE). Not all gas is } \\
\text { bought and sold on short term fixed price basis and there will } \\
\text { be longer term contracts but these will use gas price indices to } \\
\text { determine the monthly price, for example, rather than } \\
\text { competing fuel indices. Spot LNG is also included in this } \\
\text { category. }\end{array}$ \\
\hline $\begin{array}{l}\text { Bilateral } \\
\text { Monopoly (BIM) }\end{array}$ & $\begin{array}{l}\text { The price is determined by bilateral discussions and } \\
\text { agreements between a large seller and a large buyer, with the } \\
\text { price being fixed for a period of time- typically this would be } \\
\text { one year. There may be a written contract in place but often the } \\
\text { arrangement is at the Government or stat-owned company }\end{array}$ \\
\hline
\end{tabular}




\begin{tabular}{|l|l|}
\hline & level. \\
\hline $\begin{array}{l}\text { Netback from final } \\
\text { product(NET) }\end{array}$ & $\begin{array}{l}\text { The price received by the gas supplier is a function of the price } \\
\text { received by the buyer for the final product the buyer produces. } \\
\text { This may occur where the gas is used as a feedstock in } \\
\text { chemical plants, such as ammonia or methanol, and is the } \\
\text { major variable cost in producing the product. }\end{array}$ \\
\hline $\begin{array}{l}\text { Regulation: Cost of } \\
\text { Service (RCS) }\end{array}$ & $\begin{array}{l}\text { The price is determined, or approved, by a regulatory authority, } \\
\text { or possibly a Ministry, but the level is set to cover the "cost of } \\
\text { service", including the recovery of investment and a reasonable } \\
\text { rate of return. }\end{array}$ \\
\hline $\begin{array}{l}\text { Regulation: Social } \\
\text { and Political (RSP) }\end{array}$ & $\begin{array}{l}\text { The price is set, on an irregular basis, probably by a Ministry, } \\
\text { on a political/social basis, in response to the need to cover } \\
\text { increasing costs, or possibly as a revenue raising exercise. }\end{array}$ \\
\hline $\begin{array}{l}\text { Regulation: Below } \\
\text { Cost (RBC) }\end{array}$ & $\begin{array}{l}\text { The price is knowingly set below the average cost of producing } \\
\text { and transporting the gas often as a form of state subsidy to its } \\
\text { population. }\end{array}$ \\
\hline No Price (NP) & $\begin{array}{l}\text { The gas produced is either flared, or provided free to the } \\
\text { population and industry, possibly as a feedstock for chemical } \\
\text { and fertilizer plants. The gas produced maybe associated with } \\
\text { oil and/or liquids and treated as a by-product. }\end{array}$ \\
\hline Not Known (NK) & No data or evidence. \\
\hline
\end{tabular}

Source: IGU, 2012

Figure 14 is 2010 world total consumption of natural gas sorted by pricing mechanisms.

GOG took the largest part 39\% followed by OPE 23\% that was the second. Three types of regulations accounted for $33 \%$ of the total. The smallest single price mechanism category was NET at $0.6 \%$. This world price formation included both production and imports. GOG was mainly used in North America, United Kingdom and Russia; OPE was frequently used by imported gas; BIM was important to Australia, New Zealand and some of Former Soviet Union (FSU) districts; three types of regulations dominated Middle East, China and FSU. 


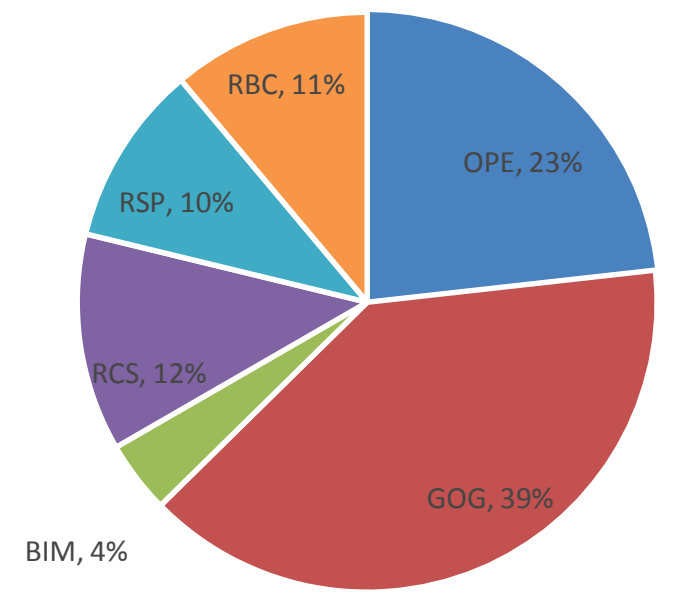

Figure 14 Used proportions of pricing mechanisms

Source: IGU, 2012

During the developing process of the natural gas market in some developed countries like the USA, UK and Canada, the pricing mechanism goes through three stages: 1. Fixed price, they mainly used the RCS. This kind of method applies to the initial stage of the natural gas development. 2. Value pricing, they mainly use NET. The prices link to that of substitutes, but regulations still exist. 3. Market competition, GOG is frequently used. Regulations are canceled; price is set by market competitions. China is still in the first stage.

In the Chinese natural gas market, the final price includes the wellhead price, the transportation fee and the distribution fee. The long-distance pipelines such as the national West-East gas pipelines are all built by the CNPC, CNOOC and Sinopec that are stateowned companies. The regional pipelines are all built by the local gas corporations that 
are public institutions, both the transportation fee related to the national pipelines and 
the distribution fee related to the regional pipelines are government guided pricing. Based on China's situation, government interventions exist in most of the energy industries. There is reason to believe that the Chinese government will regulate the midstream and downstream of the natural gas industry for a long time. Therefore, changing the pricing method of the upstream will increase the profits of the suppliers, thereby they will have incentives to produce more, even new suppliers will enter the production area, and the shortage problem might be solved. Concerning the wellhead price, marketization is the final target with the development of the natural gas industry. However, for now, RCS and NET are more practical.

The pricing method based on cost is called RCS, the final price is equal to the production cost plus a reasonable rate of return. Using RCS is able to restrict the producer's ability to capture the economic surplus, thus ensuring the gas price is as low as possible. In general, using RCS is acceptable under the following circumstances: (1) The government regulators can intervene in the upstream production when producers have market power; (2) The producer's cost (including a reasonable return) is much lower than the net back value. In practical use, RCS is usually related to the government regulation about the upstream; it applies to the initial stage of the natural gas market development.

On the other hand, RCS also has its disadvantages. First, if the number of gas fields is great, it will be very difficult and time-consuming to investigate the production costs. China does not just have a few gas fields and the number of them is definitely growing larger. Second, it is also hard to verify the cost of future exploration because exploration is often risky. Third, producers lack incentives to lower costs. According to RCS, the 
producers are certain to get a reasonable return no matter how high their production costs are; there is no encouragement for costs reduction.

The pricing method based on the market value is called NET. Using NET, the first step is to determine the terminal price. The terminal price is based on the natural gas market value; usually the alternative fuel's price is used to set the market value. The second step is to determine the city gate price. The terminal price minus the urban distribution fee equals the city gate price. The third step is to determine the upstream basic price; it equals the city gate price minus the long-distance transportation fee. This basic price is also the net back value of natural gas. The net back value is the wellhead price's upper limit, the lower limit is the price set by RCS.

Compared with RCS, NET encourages the suppliers to compete with each other, and cutting the production cost allows suppliers more profits. Using NET involves a market value, so the suppliers can get the market signals and adjust their productions to adapt to the market in a timely manner.

\subsubsection{China's pricing reform}

Considering the rapid growth of natural gas demand and the consumers' abilities to afford it, establishing an appropriate pricing mechanism is necessary. It can promote the reasonable use of energy and arouse the enthusiasm of producers, getting a win-win result for both suppliers and consumers. For a long time, China used RCS as the natural gas pricing method. This method coincided with China's natural gas market at first. However, with the development of the Chinese natural gas industry, RCS is not adequate any more. 
More gas fields are being explored; more pipelines are being built, so it's difficult for the government to regulate this kind of energy market with RCS. At the end of 2011, pilot projects were carried out in Guangdong and Guangxi provinces; the Chinese government tried to make pricing reform in these districts first. The government planned to regulate the transportation fee and service fee, using NET instead of RCS to determine the wellhead price.

NET is based on the market value, using an alternative fuel's price to determine the natural gas price. When the gas terminal price is lower than what the market can bear, the natural gas consumption will increase. For example, energy is a necessity in daily life. If the natural gas price is relatively low compared to the oil price, residents will prefer the cheaper fuel. When the natural gas terminal price is higher than what the market can bear, the natural gas consumption will decrease. At the same time, when the city gate price is higher than the production cost, the producers will try to enlarge the supply; when the city gate price is lower than the production cost, on one hand, the producers will try to reduce the cost, on the other hand, they are not willing to supply so much at a high cost. The market compares the prices of natural gas and its substitutes and chooses the appropriate fuels, then according to the city gate price, the market scale is decided. The price can be the tool to balance the supply and the demand.

Since the pilot projects have just started, the new pricing mechanism is not mature; there are a few challenges for the reform. First, people were used to consuming cheap energy in the past. The table below lists natural gas price by sector in some populous provincial capital cities in China. Besides, people doubt the rationality of rising price because they 
don't understand the production costs of energy enterprises. Considering that, Chinese pricing reform should be an evolutionary process.

Table 11 Natural gas prices in some Chinese cities

\begin{tabular}{|l|c|c|c|c|}
\hline USD/MBtu & Residential & Public services & Industry & Transport \\
\hline Beijing & 9.01 & 12.48 & 12.48 & 20.79 \\
\hline Tianjin & 9.67 & 13.85 & 13.85 & 17.36 \\
\hline Shanghai & 10.99 & 16.22 & 17.10 & 20.66 \\
\hline Nanning, Guangxi & 19.21 & 25.19 & 25.19 & 21.76 \\
\hline Shenyang, Liaoning & 13.80 & 16.31 & 16.31 & 16.31 \\
\hline Hefei, Anhui & 8.78 & 14.97 & 10.37 & 14.97 \\
\hline Wuhan, Hubei & 10.58 & 15.39 & 12.55 & 19.82 \\
\hline Chongqing & 7.19 & 9.58 & 9.37 & 19.24 \\
\hline
\end{tabular}

Note: prices have been converted from $\mathrm{CNY} / \mathrm{m}^{3}$ to USD/MBtu using and average annual conversion rate between currencies.

Source: CNPC Research Institute, 2012

Second, using NET, the terminal price is linked to the alternative fuel's prices. For example, oil, as one of the natural gas substitutes, its price fluctuates frequently and sharply. Therefore, the natural gas price is likely to change a lot following the oil price. It's a huge challenge for the downstream market to accept a variable price. Fortuately, China's oil price is relatively more stable than that of other countries because of government policy.

Third, the distribution fee is regulated by the local government, and if the local government cares more about the local profits, they may set a very high distribution fee. Therefore, the upstream will get less profits, and the inequality can cause disputes. If the local government cares more about the people's livelihood, the distribution fee is low, and local gas companies are dissatisfied. 


\section{Chapter 6: Conclusions}

Modern society pays more attention to environmental protection, and clean energies arouse peoples' interests. Compared with immature renewable energies, natural gas is much more widly used in both developing countries and developed countries. China started its natural gas industry relatively late so it's still in the initial stages. The natural gas resources are not so rich relative to the coal resources in China and the exploiting technology is not so advanced. At the same time, the Chinese government keeps a low price for the natural gas by formulating a pricing mechanism to encourage its use.

When analyzing the natural gas gap in China, this thesis looked separately at demand, supply and imports of natural gas. For demand, first, the consumptions of the four main energy sources including coal, oil, natural gas, hydro and others are compared. From 2000 to 2010 , the use of coal stayed nearly at the same level, the use of oil slightly drops, and the use of natural gas, hydro and others increased. Comparing the energy consumption structure of China and that of the world, China uses more coal because of the abundant resources; the use of natural gas in China is far behind that of the world average level. There are four reasons that natural gas is so popular among the world. First, the key components of natural gas are nontoxic; it's much safer than coal and oil. Second, natural gas is cheaper than oil products. Third, natural gas has not been a strategic tool between countries. Its supply is guaranteed follows the take or pay clause over 25 years. Last but not the least, natural gas generates much less noxious emissions than oil and coal, and using natural gas is helpful to reduce the greenhouse effect. Although China consumes less natural gas than other developed countries, the domestic consumption is 
growing very fast; the average growth rate of natural gas consumption is as high as $20 \%$ since 2004. In 2000, gas consumption was $24.5 \mathrm{BCM}$, while in 2010, the consumption jumped to 109BCM.

For supply, reserves and distributions were introduced first. China has a 56 trillion cubic meters of natural gas reserves, and they are mainly distribute in nine basins, including Tarim, Jungaar, QAidm, Sichuan, Ordos, Bohai Bay, Songliao Ying-Qiong basins and the East China Sea. Since most of the reserves are locate in western China while the main consumers are in eastern China, the Chinese government has constructed several national pipelines. The west-east gas pipeline is as long as 13,200 kilometers. Three state-owned companies, CNPC, CNOOC and Sinopec group, dominate natural gas production and pipelines. The production is also growing fast with an $13.36 \%$ average growth rate in recent years. In 2000, the gas production was 27.2 BCM; while in 2010, the production grew to $96.8 \mathrm{BCM}$.

For imports, China began to import natural gas in 2006 and one year later became a net importer. Most imports come from Australia, Qatar, Indonesia and Malaysia. In 2010, the net gas import was $12.55 \mathrm{BCM}$. Although China is able to obtain more imports, the international gas price is higher than domestic price; more imports will increase the financial burden onthe suppliers. Besides, international pipelines are expensive, import involves too many uncertainties.

Due to the low price, suppliers are not willing to produce too much while consumers are always pursuing more cost effective energy. Even if not considering the uncertainties of 
imports, imports are not able to make up the gap between the supply and demand. Therefore, although supplies increase each year, it doesn't catch up with the demand, a demand gap is inevitable. If the government doesn't deal with the gap, consumers' life will be influenced because of the gas shortage problem. More than that, the lack of energy security may result in the social instability.

To give some mathematical evidence, a system dynamics model about the natural gas demand in the future was discussed and compared with the result of a classical supply model, some estimated data about the Chinese natural gas market were obtained. In 2020, the domestic gas production will be $161.5 \mathrm{BCM}$; the domestic consumption could rise to 211.4 BCM. That means the demand gap will keep increasing under current conditions. Relying on imports is not wise and the government won't let the domestic price go up in a short time; some measures need to be taken to alleviate the shortage problem.

Unconventional gas, natural gas storage and pricing reform are three main methods of solving the demand gap. Unconventional gas's reserves are more than 150 TCM and it contributes $44.5 \mathrm{BCM}$ to supply in 2012 , so it's a potential substitute for conventional natural gas. Coal bed Methane, coal-based natural gas, SNG and shale gas are four kinds of unconventional gases. The other way is natural gas storage. Since the consumptions of natural gas in different seasons varies, natural gas storage can relieve peak seasonality. Underground storage is considered as the best way to store natural gas. The Chinese government is working on this and lots of storage facilities with large capacity will be completed in the near future. 
Over time, adjusting the price is needed. Today, the government takes control of pricing, using RCS, but it doesn't adapt to a market economy. The price can't reflect the real relationship between supply and demand. China needs a pricing reform. NET is a better pricing method for China, but there are still some problems.

Sound policies can promote and guide the evolution of energy use. Natural Gas Use Policy and the $12^{\text {th }}$ Five Year Plan on Natural Gas are two important policies in China; they guide the Chinese natural gas industry.

Through the discussion about the natural gas demand gap in China, the current market circumstances are discussed. The demand gap will affect energy security and even undermine social stability. Studying the present Chinese natural gas industry and forecasting its future indicate that China has to make changes to ensure the steady and rapid natural gas market development. Several suggestions are made to contribute to solving the gas demand gap problem. 


\section{Bibliography:}

Anne-Sophie Corbeau, Dennis Volk, Jonathan Sinton, Julie Jiang, Jiang Ping, Tammy Teng, Li Boshu and Yue Fen. "Gas Pricing and Regulation: China's Challenges and IEA Experience.” International Energy Agency, 2012.

http://www.iea.org/publications/freepublications/publication/ChinaGasReport_Final_WE B.pdf (accessed April, 2013.)

“BP Statistical Review of World energy: Natural Gas Section 2011.” BP, 2011.

“China's 12 $2^{\text {th }}$ Five-Year Plan: Energy." KPMG LLP, 2011.

http://www.kpmg.com/cn/en/IssuesAndInsights/ArticlesPublications/Documents/China12th-Five-Year-Plan-Energy-201104.pdf (accessed August, 2013.)

“Country Analysis Driefs: China.” U.S. Energy Information Administration, 2013. http://www.eia.gov/countries/analysisbriefs/China/china.pdf(accessed October, 2013.)

Chun Chun Ni. "China's Natural Gas Industry and Gas to Power Generation.” The Institute of Energy Economics Japan, 2007.

“CO 2 emissions from fuel combustion.” International Energy Agency, 2012. http://www.iea.org/co2highlights/co2highlights.pdf(accessed April, 2013.)

Catherine Locatelli. "The entry of China to the gas market: constraints and opportunities." University of Grenoble II, 2003.

“China Natural Gas Industry Guide." Platinum Broking, 2013. http://www.platinumasia.com/eng/pdf/research/2013-01ChinaNaturalGasIndustryGuide_eng.pdf (accessed May, 2013.)

David Almeida. "Challenges to China's Energy Policy." University of California, San Diego School of International Relations, 2010. http://irps.ucsd.edu/assets/039/11615.pdf (accessed September, 2013.)

Daniel H. Rosen. "China Energy: A Guide for the Perplexed. "Peterson Institute for International Economics, 2007. http://www.iie.com/publications/papers/rosen0507.pdf (accessed May, 2013.)

David J Ramberg. "The relationship between Crude Oil and Natural Gas Spot Prices and Its Stability over Time.” Massachusetts Institute of Technology, 2010.

David J. Ramberg and John E. Parsons. "The Weak Tie Between natural Gas and Oil Prices.” Massachusetts Institute of Technology, 2012. 
http://www.mit.edu/ jparsons/publications/Weak\%20Tie\%20Natural\%20Gas\%20and\%2 0Oil\%20Prices.pdf (accessed May, 2013.)

"Earthquake resistant Construction of Gas and Liquid Fuel Pipeline Systems Serving, or Regulated by, the Federal Government.” Federal Emergency Management Agency, 1992.

Jeffrey Logan. “Natural Gas and China's Environment.” Pacific Northwest National Laboratory, 2000.

http://citeseerx.ist.psu.edu/viewdoc/download?doi=10.1.1.195.5791\&rep=rep1\&type=pdf (accessed July, 2013.)

Junchen Li, Xiucheng Dong, Jianxi Shangguan and Mikael Hook. "Forecasting the growth of Chinese natural gas consumption." Energy, 2011, Voal. 36, Issue 3: 1380-1385.

James T. Jensen. “Asian natural Gas Markets Supply Infrastructure, and Pricing Issues.” Pacific Energy Summit, 2011.

http://www.nbr.org/downloads/pdfs/eta/PES_2011_Jensen.pdf(accessed June, 2013.)

Li Zhidong. "Natural Gas Use Policy Trends in China." Nagoaka University of Technology, 2013. http://eneken.ieej.or.jp/data/4878.pdf (accessed November, 2013.)

Mike Fulwood. "Wholesale Gas Price Formation 2012.” International Gas Union, 2012. http://www.igu.org/gas-knowhow/publications/igu-

publications/IGU_GasPriceReport_2012_for\%20the\%20web.pdf(accessed July, 2013.)

“Oil and Gas security: Emergency response of IEA Countries.” IEA, 2012. http://www.iea.org/publications/freepublications/publication/Hungary_2012.pdf (accessed December, 2013.)

"Study on Common Pool Price Mechanism for Natural Gas in the country." MERCADOS ENERGY MARKETS INDIA PRIVATE LIMITED, 2010.

Steven W. Lewis. "Natural Gas in the People's Republic of China." Harvard Kennedy School, 2013. http://belfercenter.hks.harvard.edu/files/CES-pub-GeoGasChinaLewis102913.pdf (accessed December, 2013.)

"The Market for Natural Gas in China: Summary of a Research Program." Stanford University, 2005. http://iis-db.stanford.edu/evnts/4398/Prospectus.pdf(accessed November, 2013.)

Xu Bo. "China's Natural Gas Industrial Development: Energy Saving \& Reduction of Emissions." CNPC Research Institute of Economics and Technology, 2009.

http://www.igu.org/html/wgc2009/papers/docs/wgcFinal00153.pdf(accessed July, 2013.) 
Yi Chen. "Development strategies of the Chinese natural gas market." CLINGENDAEL INTERNATIONAL ENERGY PROGRAMME, 2013.

Yanrui Wu. "Gas Market Integration: Global Trends and Implications for the Eas Region.” University of Western Australia, 2011.

Ying Wu, John J. Carroll. “A review of recent natural gas discoveries in China.” Gas Liquids Engineering, 2005.

http://www.gasliquids.com/papers/A_Review_of_Recent_Natural_Gas_Discoveries _in_China.pdf (accessed June, 2013.)

Zhang Jian. "China's Energy Security: Prospects, Challenges, and Opportunities.” The Brookings Institution, 2011.

http://www.brookings.edu/ /media/research/files/papers/2011/7/china\%20energy\% 20zha ng/07_china_energy_zhang_paper(accessed September, 2013.) 